\title{
CLAIMS MADE INSURANCE POLICIES IN NEW ZEALAND AND AUSTRALIA: SHOULD NEW ZEALAND ENACT A STATUTORY DEEMING REGIME?
}

\author{
BY \\ STEPHEN GRANT BOURNE
}

\begin{abstract}
A thesis
submitted to the Victoria University of Wellington in fulfilment of the requirements for the degree of

Master of Laws
\end{abstract}

Victoria University of Wellington

2012 


\section{Table of Contents}

I. Introduction - 5

II. About Claims Made Insurance - 9

III. Equity Preserved - 16

IV. New Zealand Without Section 9 of the Insurance Law Reform Act 1977 - 31

V. The Australian Experience - 37

VI. New Zealand After 1977 - 73

VII. Arguments For and Against Enacting a Statutory Deeming Provision in New Zealand - 80

VIII. Conclusion - 86

IX. Appendix (sections of relevant Acts) - 88

X. Bibliography - 91 


\section{Abstract}

A claims made policy protects an insured person or business in relation to claims made against that person or business during the policy period, regardless of when the cause of loss occurred, and regardless of when the claim is notified to the insurer (subject always to the terms of cover and the relevant law). The trigger event for a claim against the insurer is the receipt of the claim or demand by the insured. However, issues can arise when the insured has knowledge of circumstances that may lead to a claim, but the claim itself is delayed, a situation sometimes addressed by way of a contractual 'notice of circumstances' provision coupled with a deeming provision. The proposition in this dissertation is that New Zealand should have a statutory deeming regime affecting claims made insurance policies, similar to that contained within section 40 of Australia's Insurance Contracts Act 1984 (Cth). However, to properly consider that proposition, it is necessary to review the context within which section 40 arose, its practical effect in that context, and the perceived issues that might be addressed in New Zealand by way of a statutory deeming regime. In particular, it is necessary to acknowledge the juxtaposition of sections 40 and 54 of the Insurance Contracts Act (Cth), and the implications of section 9 of New Zealand's Insurance Law Reform Act 1977.

\section{Word length}

The text of this paper (excluding abstract, table of contents, footnotes and bibliography) comprises approximately 32,500 words.

\section{Subjects and Topics}

Insurance - Claims made insurance policies.

Equity - Rules as to when time is of the essence.

Contracts - Intermediate and innominate terms.

Insurance Law Reform Act 1977, section 9.

Contractual Remedies Act 1979, section 7(4).

Insurance Law Reform Act 1985.

Judicature Act 1908, section 90.

Insurance Act 1902 (NSW), section 18.

Law Reform (Miscellaneous Provisions) Act 1946 (NSW), section 6.

Instruments Act 1958 (Vic), section 27.

Insurance Contracts Act 1984 (Cth), sections 40 and 54. 
This dissertation is dedicated to the people who give us google, austlii, nzlii and wikipedia. ${ }^{1}$ They are gods amongst men.

${ }^{1}<w w w . g o o g l e . c o m>,<w w w . a u s t l i i . e d u . a u>,<w w w . n z l i i . o r g>,<w w w . w i k i p e d i a . c o m>$. 


\section{Introduction}

The thesis here is that New Zealand should have a statutory deeming regime affecting claims made insurance policies, similar to that contained within section 40 of Australia's Insurance Contracts Act 1984 (Cth). However, to properly consider that proposition, it is necessary to review the context within which section 40 arose, its practical effect in that context, and the perceived issues that might be addressed in New Zealand by way of a statutory deeming regime. In particular, it is necessary to acknowledge the juxtaposition of sections 40 and 54 of the Insurance Contracts Act, and the implications of section 9 of New Zealand's Insurance Law Reform Act 1977. For reference, these three legislative provisions are set out in full in Appendix 1.

To assist the reader, it is useful to note that my review takes the following course, after this introduction:

- About Claims Made Insurance. A summary of what constitutes a claims made policy, how it operates, and information about other types of policies that are commonly underwritten.

- Equity Preserved. The statutory regime we now have is effectively a modification of the common law, to some degree reflecting rules that were evolved in the Courts of Chancery. This chapter reviews the history, and introduces the rent review cases, which arguably show a significantly changed view of time stipulations in contracts.

- New Zealand Without Section 9 of the Insurance Law Reform Act 1977. This chapter discusses the notion that section 90 of New Zealand's Judicature Act 1908 may now, in the light of Hongkong Fir and United Scientific (see later), have a similar effect to section 9 of the Insurance Law Reform Act 1977.

- The Australian Experience. By way of the Insurance Contracts Act 1984 (Cth), Australia has both an equivalent to New Zealand's section 9, and a statutory deeming regime. This chapter considers the interplay between sections 54 and 40 of the Australian legislation, and reviews relevant judgments. The judgments are complex, but have been selected to convey a view of the implications of Australian Hospital Care (also see later), and how section 54 has subsequently been engaged in terms of that case. 
- New Zealand After 1977. That year, 1977, marked the introduction of section 9 of the Insurance Law Reform Act. This chapter includes reference to leading cases bearing on the interpretation and effect of section 9 .

- Arguments For and Against Enacting a Statutory Deeming Provision in New Zealand.

- Conclusion.

However, before we continue, it is appropriate to introduce the claims made insurance policy.

Consider this hypothetical scenario: Joe, a successful financial advisor, has just completed his 10th year in business. The recent economic recession is looking more distant every day that passes, and experienced financial advisers like Joe are enjoying a steady increase in new clients. However, just as Joe reaches his office one day, a letter arrives. It's from lawyers acting for one of his former clients, Bob Smith. Bob was one of the "unlucky" ones: all his savings were invested in MFS, a now-defunct finance company, and he lost the lot. Although Joe hasn't seen Bob for nearly two years, he vividly recalls Bob's anger at learning about the loss of his savings. Bob had demanded that Joe reimburse his losses ... "It was your advice I followed ... it was your fault ... I'll sue you", he'd said. However, Joe didn't hear from Bob again after that. Until now. Joe looks at the lawyers' letter, and sees that Bob is seeking over $\$ 500,000$, alleging "negligence" by Joe.

"It's just as well I've got insurance for this," Joe says to himself.

Joe then tracks down his current Professional Liability Insurance policy, which was taken out just a few weeks ago. The insurance company had offered a much lower price than Joe's previous insurer, so Joe made the switch when the old policy came up for renewal.

The first page of the current policy contained a section headed "Notice to the Insured", which included the following:

This policy provides cover on a claims made and notified basis. 
A claim must be made against the insured during the period of insurance.

The insured must notify the insurer in writing of such claim during the period of insurance.

Joe feels reassured by this, and contacts his insurance broker to get a claim form. While completing the claim form he comes to the question "State the date you first became aware of the possibility that a claim might be made." Joe writes down the date when Bob confronted him nearly two years ago.

A few weeks later, the insurance company tells Joe his claim is declined... because Joe failed to disclose Bob's earlier demand, when Joe applied for the new policy. The very next day, Joe gets a further letter from Bob's lawyers, threatening to start court proceedings if payment is not made "forthwith." Joe gets out his old liability policy. After all, Bob's demand was made when that policy was in force... "Perhaps that insurance company will meet the claim", he thinks. However, the terms of that policy are much the same as the current one, requiring Joe to give notice to the insurer during the period of insurance. Now, instead of his insurance company handling the claim, and their lawyers dealing with Bob's lawyers, Joe will need to engage a lawyer at his own cost, and may end up having to sell his home or take out a larger mortgage to pay Bob's claim. Even if Bob is unsuccessful, Joe could be left with significant legal bills.

Unlike conventional policies, such as building and vehicle insurance, which are on an occurrence basis, Professional Liability Insurance covers are claims made, or claims made and notified. ${ }^{2}$ Although Joe's case is hypothetical, variations of this scenario are all too common, as professionals and businesses wrestle with the complexity of claims made insurance policies.

The big advantage - to insurers - of claims made policies, is that the amount of claims for a particular cover period can be determined shortly after expiration of the policy. If, instead, claims were paid against policies in force when relevant negligent acts or omissions occurred, the delay in losses being notified could require an insurer to keep its books open for many years in relation to each policy - and would delay the calculation of its profit or loss arising from each policy year overall.

${ }^{2}$ For convenience, from here on, references in this dissertation to "claims made" will typically include claims made and notified, unless indicated otherwise. The distinction is discussed in Chapter II. 
However, an insurer offering claims made cover will want to be sure potential claims are identified (and excluded), where possible, before it goes on risk. This effectively forces an insured person or business to identify all potential claims, and give appropriate notice to the insurance company whose policy is in force at that point in time. Unfortunately, however, identifying a potential claim requires an insured person or business to be alert to circumstances where negligence might have occurred, even if liability is unknown or unlikely. A real-life example of this is found in Jacobs $v$ Foster, ${ }^{3}$ where a customer was injured after slipping on diesel fuel spilt on the forecourt of the insured's petrol filling business. The Court of Appeal in England adopted an "objective test", based ostensibly on the lack of evidence to show that the insured knew of anything being wrong with the forecourt, but perhaps also influenced by the Court's assessment that the nature of the victim's injuries was not such that she was more likely than not to make a claim. Fortunately for the insured, the Court - demonstrating a reluctance to concede that society had reached "such a sorry state" that it should be assumed that such victims would make a claim - found the insured was not in breach of an obligation to give immediate notice of circumstances "likely" to give rise to a claim.

Returning to our hypothetical example, a person or business in Joe's situation might not be as fortunate as the insured in Jacobs. Where a potential claim is not identified and notified during the correct insurance period, the insured may well end up having to bear the loss themselves.

3 Jacobs v Foster [2000] Lloyds Rep 506. 


\section{About Claims Made Insurance}

\section{A What is claims made insurance, and how does it work?}

People who primarily use insurance to protect physical assets, such as houses and cars, will be familiar with occurrence-based insurance, which covers loss or damage occurring within the policy period, regardless of when it is discovered. However, occurrence-based insurance is not suitable for some risks, such as where a loss might not be discovered until many years after the policy period ends. For such risks, insurers usually offer claims made, and claims made and notified, policies.

A claims made policy protects the insured person or business in relation to claims made against that person or business during the policy period, regardless of when the cause of loss occurred, and regardless of when the claim is notified to the insurer. The trigger event for a claim against the insurer is the receipt of the claim or demand by the insured.

In Australia \& New Zealand Bank Ltd v Colonial \& Eagle Wharves Ltd, ${ }^{4}$ McNair J gave consideration to how the word "claim" should be interpreted, and concluded, depending on the context, that the word refers to a right to make a claim, or an assertion of a right to make a claim. In relation to a claims made policy, the appropriate interpretation is the latter. Accordingly, mere information about the possibility of a claim, without a demand or assertion of the claimant's right against the policyholder, falls short of a claim.

Nonetheless, most claims made policies require a policyholder, who has knowledge of a potential claim, to give that information to the insurer. This enables the insurer to undertake relevant inquiries, and address underwriting issues. However, the claim itself, if there is one, may fall to be paid by the insurer who has underwritten the insurance coverage for the period (either the current period or a later one) when the claim is actually received by the policyholder, unless the current policy says otherwise.

In Gosford City Council v GIO General Ltd, ${ }^{5}$ Sheller JA considered the difference between 'claims made' and 'claims made and notified' policies:

${ }^{4}$ Australia \& New Zealand Bank Ltd v Colonial \& Eagle Wharves Ltd [1960] 2 Lloyd's Rep 241 at 255.

${ }^{5}$ Gosford City Council v GIO General Ltd [2003] NSWCA 34, (2003) 56 NSWLR 542, (2003) 12 ANZ Ins Cas 61-566, BC200300808. 
The distinction between the two is that in the first the insured's right to indemnity, if unmodified by statute, depends upon a claim being made against the insured during the period of insurance and in the second upon such a claim being not only made against the insured but also notified to the insurer during the period of insurance. ${ }^{6}$

Accordingly, a claims made and notified policy - sometimes called a claims made and reported policy - will protect the insured person or business in relation to claims made against that person or business during the policy period, regardless of when the cause of loss occurred, but only where the insurer is notified of the claim within the policy period (or within such further period as is specified in the policy, if it has a grace period). The trigger event is the combination of the receipt of the claim or demand by the insured, and the subsequent notification of that claim to the insurer.

In view of the claim receipt (by the policyholder) being the trigger for indemnity, a person or business with claims made insurance for professional liability risks will be concerned to ensure that cover continues until such time as all possible claims relating to activity in an earlier period are to hand, so as to be sure such claims will be covered. It is important to keep in mind that knowledge of facts which may lead to a claim is not the same as receiving a claim, so an insured may not be able to notify the insurer of a 'claim', so as to lock it into the current insurance period, when the relevant circumstances first come to light. However, in relation to a claims made policy, a policyholder's delay in notifying the insurer that the claim has been received will not prevent it being paid when it is eventually passed on to the insurer.

While claims made and notified cover is the more commonplace of the two types of cover, it is more onerous for the insured. In order to have a valid claim, the insured must recognise that a claim has been made - which can sometimes be difficult to identify, if a demand is couched in ambiguous or informal terms - and must then notify the insurer within the policy period or a specified period. Failure to give notification in time may lead to the insurer refusing to pay the claim.

For example, in a recent court case decided in the US, Farm Bureau Life Ins Co v Chubb Custom Ins $\mathrm{Co}^{7}$ the Iowa Supreme Court held, in relation to a claims made and reported policy, that written notice to the insurer within the policy period was "a condition

${ }^{6}$ [2003] NSWCA 34, above n5, at [3].

${ }^{7}$ Farm Bureau Life Ins Co v Chubb Custom Ins Co 2010 WL 1404976 (Iowa, 9 April 2010). 
precedent" to coverage. Accordingly, the policyholder's failure to report a claim to the insurer within the prescribed period led to that claim being disallowed.

Moreover, as was noted in QBE Insurance Ltd $v$ Attorney-General, ${ }^{8}$ a 'claim' cannot be reported to an insurer before it has been notified to the insured. ${ }^{9}$ The policy in $Q B E$, referred to by the Court as a hybrid policy, had characteristics that ultimately proved disastrous for the Crown (the Attorney-General being on the record for the Ministry of Agriculture and Fisheries):

As a hybrid claims made policy, under which circumstances of apprehended claims had to be notified, it entailed the risk that notification might be required during the term of the policy under which no claim could be made in the absence of a third party demand. Such risk entailed the further risk of insurers' refusing to continue to indemnify for later years or agreeing to do so only on terms of excluding notified claims: it was not suggested for the Crown that HIH or QBE had committed to continue to provide insurance on any particular basis or at all. Whether or not MAF could have negotiated for a modification of Exclusion 6 in the ensuing policies to exclude risks already notified, that did not occur. ${ }^{10}$

Both claims made policies and claims made and notified policies may optionally include a 'notification of circumstances' clause, which typically allows - or requires - an insured to give notice of relevant circumstances (information about a possible claim) to the insurer within the policy period. This may be coupled with a deeming provision, so that the insured giving such notice is deemed to have received and reported a claim falling under the policy, thereby protecting the insured's position even if the formal claim is not received until much later. The claim will be met by the policy for the period during which the claim or potential claim is first reported.

A significant feature of $Q B E$, alluded to in the extract from that case quoted above, was the absence of a deeming provision. For the insurer it was argued that:

The 1998-1999 policy did not contain the Condition 5 which appeared in policies from 30 June 1999. Had it contained a Condition 5, deeming a claim the circumstances of which were notified during its period to have been made within that

${ }^{8}$ QBE Insurance Ltd v Attorney-General [2005] NZCA 193, BC200561103.

${ }^{9}$ [2005] NZCA 193, above n8, at [26].

${ }^{10}$ [2005] NZCA 193, above n8, at [41]. 
period, its cover would have embraced the claim. But the parties did not stipulate for such a clause and the loss is simply not covered by that policy. ${ }^{11}$

For its part, the Crown argued that MAF was entitled to rectification "to give effect to a common intention that the policy would cover risks arising from losses founded upon circumstances notified during the term of that policy." ${ }^{12}$ This argument by the Crown, and other submissions which sought to have the Court write a deeming clause into the policy for that 1998-1999 year, were rejected by the Court:

To accept the Crown's implied term argument would require this Court to depart fundamentally from the settled principle that insurance policies like any other contract are to be construed in accordance with the plain language selected by the parties. $^{13}$

\section{B Why property insurance is usually occurrence based, not 'claims made'}

Most consumers of property insurance products expect their policy will pay out for a claimable incident that occurs during the policy period - that is, during the period for which premiums are paid. Accordingly, if a fire or accident occurs the day after the policy period ends, it will not be covered under the relevant policy, unless the policy has been renewed. If, on the other hand, water damage from a flood occurs during the policy period, but is not discovered until after the policy period ends, the claim will nonetheless be lodged against the policy in force at the time of the flood. These are examples of occurrence-based insurance in operation.

Such insurance is suitable for situations where knowledge of an insured event - for example, a fire or accident - is likely to quickly follow the event itself, so that in most cases a claim on the insurer can and will be lodged during the policy period or soon after the policy period ends.

However, certain types of insurance cover are more typically provided on a different basis. For example, sometimes ships and cargoes may be insured on a 'lost or not lost' basis, and professional indemnity insurance is usually provided on a 'claims made' basis.

\footnotetext{
${ }^{11}$ [2005] NZCA 193, above n8, at [18].

12 [2005] NZCA 193, above n8, at [28].

${ }^{13}$ [2005] NZCA 193, above n8, at [41].
} 


\section{Lost or not lost}

'Lost or not lost' means the parties (insurer and insured) do not know whether the subjectmatter of the insurance is still in good condition at the time when cover commences, but nonetheless agree the insurer will honour a valid claim even if an incident giving rise to a claim occurred before cover commenced. This is a useful type of cover, or policy extension, where, for example, a ship or cargo is at sea and there is no easy way to be sure of its condition. In earlier times, when communication with ships at sea was limited, such policies were quite common. Nowadays, they are less common in relation to ships, but are still sometimes used for cargoes - as the condition of a cargo may not be evident until the ship or aircraft arrives at its destination. Lost or not lost insurance is still technically occurrence-based, as it will be assumed (if a loss occurs) that an incident causing the loss happened during the policy period.

\section{Claims made}

As we have seen earlier, claims made insurance policies only cover claims lodged within the policy period, or, in some cases, within a defined period after the policy period ends. Such policies are typically used for types of cover where a claim might occur many months or years later, when a loss becomes known. For example, in the case of an architect's professional indemnity cover, a problem with the design of a building (arising from the architect's negligence) might not become evident until after a major weather event, or from the cumulative effect of normal weather patterns, perhaps many years later. In this case, the loss should be covered by the policy in force when the claim is notified, not the policy for the period during which the negligence occurred.

Could more common insurance covers, such as house and car insurance, be conducted on a 'lost or not lost' or 'claims made' basis? The simple answer is no. Insurers will usually only grant lost or not lost cover where they are satisfied the subject-matter of the insurance is probably in good order and condition - such as where they can see a Bill of Lading proving a cargo was in good condition when loaded onto a ship - but where there is nonetheless some uncertainty shared by both insurer and insured. In the case of a house or car, or other land-based asset, its condition at a point in time (when the insurance cover is being arranged) can more easily be ascertained. 
Similarly, an insurer will not issue claims made insurance for an asset that is already known to be lost or damaged. Whereas an architect's future professional liability risk (arising from current projects) cannot be fully ascertained immediately, the destruction of a physical asset can usually be confirmed at any time.

\section{Late claim declined?... It may not be the end of the story}

In simple terms, purchasers of insurance products reasonably expect their claims will be paid for occurrences inside the scope of cover arranged. They may also agree that occurrences outside the scope of cover will not be paid.

However, a claim can also be declined where a pre-condition is not met.

Sometimes insurance policies contain a term or condition requiring all claims to be notified or lodged within the policy period, or promptly after the loss becomes known, or before the expiration of some other specified deadline. An example of such a policy condition is a follows: ${ }^{14}$

... you or an insured person must ... call us ... as soon as possible when you discover that an incident likely to result in a claim has occurred.

and

... you or an insured person must NOT ... delay contacting us whenever possible to notify us of an incident which could lead to a claim on this policy. You may have to contribute towards your claim if your late notification results in higher costs for us or harms our investigation opportunities.

This introduces the risk - for an insured - that a legitimate claim is avoided or reduced by the insurer, because of late notification. However, late notification occurs for a variety of reasons, many of them outside the control of the insured, and is not usually prejudicial that is, in most cases the insurer is not adversely affected by the delay, and the claim payout will be no greater than if the claim was lodged within the specified deadline.

In response to consumer pressure, insurance law in Australia and New Zealand has been changed to ensure such deadlines do not unfairly disadvantage policyholders - both

${ }^{14}$ QBE Insurance (Australia) Limited "Motor Vehicle Policy" (Australia, 30 May 2010). 
countries' statutory regimes include provisions affecting insurers' ability to rely upon such notice requirements. Therefore, although insurance companies will look to the terms and conditions of a claimant's policy, when they are deciding whether a claim should be paid or not, they must also consider the statutory regime which governs insurance contracts.

The effect of the law as it stands now is relatively clear, at least in terms of decided cases, but (to steal a phrase from Burrows, Finn \& Todd) it "does not follow... that it is possible to explain the modern law without reference to its history."15 The statutory regimes, referred to in the previous paragraph as affecting insurers' ability to rely upon notice requirements, are modifications to the common law.

As long ago as $1779,{ }^{16}$ a common law rule was established which said that contractual promises by one party were "conditions precedent" to the contractual promises of the other party, such that even a minor breach by one party might discharge the other from his or her obligations under the contract.

Although the common law judges themselves sought to soften the impact of this rule, by way of exceptions to it, the rules of equity (developed by the Courts of Chancery) evolved to regard contractual promises as more akin to warranties than conditions precedent. Modern laws that modify the common law are typically giving effect to the considerations and notions of fairness that drove the development of rules of equity in the Courts of Chancery. As will be seen in the next chapter, the starting point, upon the abolition of the separate Courts of Chancery, was the adoption of a statutory rule requiring courts thereafter to give contractual stipulations "the same construction and effect" as would have been the case in equity. ${ }^{17}$

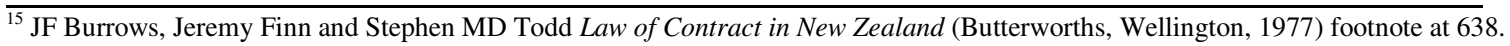

${ }^{16}$ Boone v Eyre, 1 Hy B1 723n, 1779.

${ }^{17}$ Judicature Act 1908, section 90.
} 


\section{Equity Preserved}

\section{A Court of Chancery Abolished - But Equity Lives On}

The law of contract in New Zealand is arguably a creature of the common law - derived in the first instance from precedents judicially evolved over several centuries in the United Kingdom and Commonwealth jurisdictions - although modified by statutory provisions such as those contained in the Frustrated Contracts Act 1944, the Illegal Contracts Act 1970, the Contractual Mistakes Act 1977, the Contractual Remedies Act 1979, the Contracts (Privity) Act 1982, and the Property Law Act 2007 (which incorporates some provisions formerly found in the Contracts Enforcement Act 1956). However, long before these statutory changes were enacted, the Court of Chancery in the United Kingdom (abolished as a separate court by the Supreme Court of Judicature Act 1873) ${ }^{18}$ had recognised rights arising from ethical concepts, which in some cases were found to be available to address injustices arising from common law rules affecting contracts. One such common law rule was that time was "of the essence" in relation to the performance of a contract, even if that was not an express provision of the contract. Equity, on the other hand, said that time was not necessarily of the essence - opening the door to remedies that the common law would not countenance.

In the United Kingdom, after the abolition of separate courts of equity, the Law Amendment Act 1882 amended several rules of law, so as to preserve certain specific rights arising in equity (in addition to addressing the custody of infants and the matter of parties to partition suits). Of relevance here, Section 8 of the Law Amendment Act provided that "stipulations in contracts as to time or otherwise which would not, before the coming into operation of this section, have been deemed to be or have become the essence of such contracts in a Court of Equity, shall receive in all Courts the same construction and effect as they would have heretofore received in Equity." This provision was later imported into the Law of Property Act 1925, in the United Kingdom, as section 41 of that Act:

Stipulations in a contract, as to time or otherwise, which according to rules of equity are not deemed to be or to have become of the essence of the contract, are also construed and have effect at law in accordance with the same rules.

${ }^{18}$ Supreme Court of Judicature Act 1873 (UK) 36 \& 37 Vict c 66. 
With very minor (and inconsequential) amendment, this provision has also found its way into New Zealand's Judicature Act 1908, as section 90 of that Act - viz:

Stipulations in contracts as to time or otherwise which would not, before 13 September 1882 (the date of the coming into force of the Law Amendment Act 1882), have been deemed to be or to have become the essence of such contracts in a court of equity shall receive in all courts the same construction and effect as they would have theretofore received in equity.

\section{$B$ Ameliorating the Asperities of the Common Law}

A common effect of this statutory rule is to allow a court, in appropriate circumstances, to determine that the breach of a contract's time provision, by a party to that contract, does not necessarily give another party the right to treat that contract as at an end - under equity, the late performance may give the aggrieved party a right to claim specific performance, for example, rather than a right to terminate the contract. In Re Sandwell Colliery Co, ${ }^{19}$ Maughan J said:

Courts of Equity, dealing with actions for specific performance relating to land, have been accustomed to give effect to the real intention rather than the precise words fixing the date for completion. The effect is that a Court fixing the date of completion is equivalent to a Court stating that completion shall be on that date or a reasonable time thereafter. ${ }^{20}$

Similarly, although earlier in time, Earl Loreburn in the House of Lords in Stickney $v$ Keeble, ${ }^{21}$ said:

I will merely observe that the date fixed for completion in a contract for the sale of land is no less a part of the contract than any other clause, but Equity will grant relief where a party seeks to make an unfair use of the letter of the contract in this respect, having regard to the state of the law relating to real property in England. It is safe to say that this relief will always be refused when to grant it would be essentially unfair. $^{22}$

\footnotetext{
${ }^{19}$ Re Sandwell Colliery Co [1928] ER Rep 651.

${ }^{20}$ [1928] ER Rep 651, above n19, at 653.

${ }^{21}$ Stickney v Keeble [1914 to 15] ER Rep 73.

${ }^{22}$ [1914 to 15] ER Rep 73, above n21, at 77.
} 
Both of these decisions, and others, are referred to in the more recent judgment of the House of Lords in Raineri $v$ Miles \& Anor. ${ }^{23}$ That case arose from a cascade failure in relation to property settlement, where the defendants were initially unable to complete the sale of their house, because the vendors of another house to which they were moving could not complete that contract in time. Although the Court in that case, in considering the culpability of the first vendor (the third parties from whom the defendants were intending to purchase) determined that the express terms of the contract preserved the defendants' rights against the third parties, the judgment is useful to the extent it identifies the effect of the relevant rule of equity, whereby the defendants would have been entitled to an order requiring specific performance, which would undoubtedly have brought the contract to an end upon the third parties' failure to comply with that order.

The key question in Raineri was whether the failure by a party to complete the contract by the stipulated completion date amounted to a breach of contract even though the time for completion was not regarded in equity as "of the essence". The third parties argued that they were never in breach of their contract, in view of them having settled within the period of the notice given them by the defendants (requiring the third parties to complete the contract within 28 days). Both the Court of Appeal and the House of Lords concluded that the failure to complete by the date specified in the contract was a breach of the contract, under the common law and in equity, and the former Courts of Chancery would not "re-write contracts nor did they hold that a man who had broken his word had kept it ... but what they did in proper circumstances was to ameliorate the asperities of the common law." 24

\section{Statutory Limitation on the Right to Cancel}

As noted earlier, the Contractual Remedies Act 1979 is one of the New Zealand statutes that modifies the common law in relation to contracts. In circumstances where a party has been induced to enter a contract by a misrepresentation, or a party has broken (or will break) a term of a contract, section 7(4)(a) of the Contractual Remedies Act 1979 says the aggrieved party may exercise a right to cancel if (and only if) the parties agreed that the truth of the representation or performance of the term is essential, or the effect of the misrepresentation or breach is or will be to substantially reduce the benefit of the contract

${ }^{23}$ Raineri v Miles \& Anor [1980] 2 All ER 145, [1981] AC 1050.

${ }^{24}$ [1980] 2 ER 145, above n23, at 153. 
(or increase the burden of the contract) to the cancelling party, or will make the benefit or burden substantially different from that represented or contracted for.

On the face of it, at least in effect, section 7(4)(a) of the Contractual Remedies Act is consistent with section 90 of the Judicature Act in relation to contracts where the parties have expressly or impliedly agreed that the performance of the contract term (for example, as to time) "is essential" to one or both of them. In that case, section 7(4)(b) applies, and the aggrieved party is free to terminate the contract. Similarly, in relation to contracts where "time is of the essence", using equity's shorthand, equity may reach the same conclusion.

\section{Intermediate Terms: The Tortuous History Behind Rent Review Cases}

No discussion about section 90 of New Zealand's Judicature Act, in relation to commercial contracts, would be complete without mention of rent review cases. Such cases typically involve a landowner's failure to give, before the deadline in the lease contract, notice of a rent increase. Unsurprisingly, that deadline having passed, the tenant contemplates the prospect of a windfall in the form of saved rent.

However, a substantial body of law has established that, unless the parties have agreed that "time is of the essence," a late review is still effective. A leading authority is United Scientific Holdings Ltd v Burnley Borough Council, ${ }^{25}$ where the House of Lords rejected argument that the landlord's failure to notify an increase by the rent review date in the lease had cost landlord the opportunity to raise the tenant's rent. The essence of the rationale behind the House of Lords decision is that there is no prejudice to the tenant arising from the landlord's delay, and (relying on the United Kingdom equivalent of New Zealand's section 90, at that time) equity should intervene in the interests of fairness between the parties. Martin $(2005)^{26}$ refers to their Lordships' reasoning as illustrating "commercial realism", in circumstances where (per Martin):

... a periodic review of the rent is such an important part of the original bargain between landlord and tenant that those parties cannot be supposed to have intended

\footnotetext{
${ }^{25}$ United Scientific Holdings Ltd v Burnley Borough Council [1978] AC 904, [1977] 2 All ER 62.

${ }^{26}$ John Martin "A timing issue" (21 March 2005) Property Law Journal 146 at 2.
} 
that the right to that review should be lost merely because of failure to take a particular step in time. $^{27}$

However, Lord Diplock, driving off the concept of the 'intermediate' or 'innominate' term as conceived in Hongkong Fir Shipping Co Ltd $v$ Kawasaki Kisen Kaisha Ltd, ${ }^{28}$ drew a longer bow in United Scientific:

I see no relevant difference between the obligation undertaken by a tenant under a rent review clause in a lease and any other obligation in a synallagmatic contract that is expressed to arise upon the occurrence of a described event, where a postponement of that event beyond the time stipulated in the contract is not so prolonged as to deprive the obligor of substantially the whole benefit that it was intended he should obtain by accepting the obligation. ${ }^{29}$

Note: 'synallagmatic' usually means bilateral. See also Harvela Investments Ltd $v$ Royal Trust Co of Canada Ltd, ${ }^{30}$ and United Dominions Trust (Commercial) Ltd v Eagle Aircraft Services Ltd. $^{31}$

It should be recorded at this juncture that Lord Diplock himself did not adopt the terms 'intermediate' and 'innominate' in Hongkong Fir - as Carter, Tolhurst \& Peden (2006) observe: ${ }^{32}$

The only hint of intermediate term is to be found in the catchwords in the Queen's Bench report which include the expression 'intermediate stipulation'. Yet in the 40 odd years since Hongkong Fir the decision has become synonymous with a tripartite classification of contractual terms as conditions, warranties and intermediate (or 'innominate') terms. However, it was never adopted by Lord Diplock. Instead, he preferred to focus on the breach and in Photo Production Ltd $v$ Securicor Transport Ltd used the description 'fundamental breach' to encapsulate the type of breach which it is necessary for the promisee to prove. ${ }^{33}$

\footnotetext{
${ }^{27}$ Martin, above n26, at 2.

${ }^{28}$ Hongkong Fir Shipping Co Ltd v Kawasaki Kisen Kaisha Ltd [1962] 2 QB 264.

${ }^{29}$ [1978] AC 904, above n25, at 931.

${ }^{30}$ Harvela Investments Ltd v Royal Trust Co of Canada (CI) Ltd [1985] Ch 103, [1986] AC 207.

${ }^{31}$ In United Dominions Trust (Commercial) Ltd v Eagle Aircraft Services Ltd [1968] 1 All ER 104 at 108, [1968] 1 WLR 74 at 82, Diplock LJ preferred synallagmatic to bilateral, as there could be more than just two parties involved in a contract.

${ }^{32}$ JW Carter, GJ Tolhurst and Elisabeth Peden "Developing the Intermediate Term Concept" (Journal of Contract Law, 2006) 268 at 271.

${ }^{33}$ Photo Production Ltd v Securicor Transport Ltd [1980] UKHL 2.
} 
Accordingly, Lord Diplock's speech in Hongkong Fir moved the debate away from the issue of whether a contract term is a condition or a warranty, by focusing on the significance of the breach weighed against the purpose of the contract. Subsequently, United Scientific went beyond "breach", extending the concept of the intermediate term to include an event that is postponed (for example, the issuing of a rent review notice), at least in circumstances where a correlation can be found between the event and the "whole benefit" arising to the relevant party under the contract.

Photo Production was decided shortly before United Scientific. It was a case about enforceability of an exception clause, and their Lordships were not minded to interfere with the express words that the parties themselves had agreed. Lord Salmon considered that:

Any persons capable of making a contract are free to enter into any contract they may choose: and providing the contract is not illegal or voidable, it is binding on them ... the present contract was binding on each of the parties to it. In the end, everything depends on the true construction of the clause in dispute... [the words of which are] crystal clear... [and] incapable of any other meaning. ${ }^{34}$

As noted by Carter, Tolhurst \& Peden (2006), ${ }^{35}$ Lord Diplock used the term "fundamental breach", which he defined as a breach "which entitles the party not in default to elect to terminate the contract." Expanding on the underlying principle, Lord Diplock said:

A basic principle of the common law of contract, to which there are no exceptions that are relevant in the instant case, is that parties to a contract are free to determine for themselves what primary obligations they will accept ... if the parties wish to reject or modify primary obligations which would otherwise be so incorporated [by implication of law], they are fully at liberty to do so by express words ... Since the obligations implied by law in a commercial contract are those ... which a reasonable businessman would realise that he was accepting when he entered into a contract of a particular kind, the court's view of the reasonableness of any departure from the implied obligations which would be involved in construing the express words of an exclusion clause in one sense that they are capable of bearing rather than another is a relevant consideration in deciding what meaning the words were intended by the parties to bear. But this does not entitle the court to reject the exclusion clause,

\footnotetext{
${ }^{34}$ [1980] UKHL 2, above n33, at 11.

${ }^{35}$ JW Carter, GJ Tolhurst and Elisabeth Peden "Developing the Intermediate Term Concept" (Journal of Contract Law, 2006) 268 at 271.
} 
however unreasonable the court itself may think it is, if the words are clear and fairly susceptible of one meaning only. ${ }^{36}$

Although Lord Diplock put the matter in terms of the common law of contract, it was notable, as identified by Lord Wilberforce, that recent legislative changes had affected consumer contracts and contracts based on standard terms, while leaving commercial contracts to their own devices:

The doctrine of 'fundamental breach' in spite of its imperfections and doubtful parentage has served a useful purpose. There was a large number of problems, productive of injustice, in which it was worse than unsatisfactory to leave exception clauses to operate ... But since then Parliament has taken a hand: it has passed the Unfair Contract Terms Act 1977. This Act applies to consumer contracts and those based on standard terms and enables exception clauses to be applied with regard to what is just and reasonable. It is significant that Parliament refrained from legislating over the whole field of contract. After this Act, in commercial matters generally, when the parties are not of unequal bargaining power, and when the risks are normally borne by insurance, not only is the case for judicial intervention undemonstrated, but there is everything to be said, and this seems to be Parliament's intention, for leaving the parties free to apportion the risks as they think fit and for respecting their decisions. ${ }^{37}$

In New Zealand, section 4(1) of the Contractual Remedies Act 1979 similarly adopts a "fair and reasonable" test in relation to contractual provisions that purport to preclude a court from inquiring into or determining certain matters relating to preliminary statements, promises and undertakings which amount to representations or terms of the contract.

Lord Diplock's position in Photo Production was followed soon afterwards in Bunge Corporation v Tradax $S A,{ }^{38}$ where Lord Wilberforce said:

It remains true, as Lord Roskill has pointed out in Cehave N.V. v. Bremer Handelsgesellschaft m.b.H. [1976] 1 Q.B. 44, that the courts should not be too ready to interpret contractual clauses as conditions. And I have myself commended, and continue to commend, the greater flexibility in the law of contracts to which Hong Kong Fir points the way (Reardon Smith Line Ltd. v. Hansen-Tangen [1976] 1

\footnotetext{
${ }^{36}$ [1980] UKHL 2, above n33, at 7-8.

${ }^{37}$ [1980] UKHL 2, above n33, at 3-4.

${ }^{38}$ Bunge Corporation v Tradax SA [1981] UKHL 11, (1981) 1 WLR 711.
} 
W.L.R. 989, 998). But I do not doubt that, in suitable cases, the courts should not be reluctant, if the intentions of the parties as shown by the contract so indicate, to hold that an obligation has the force of a condition, and that indeed they should usually do so in the case of time clauses in mercantile contracts. To such cases the "gravity of the breach" approach of Hong Kong Fir would be unsuitable. I need only add on this point that the word "expressly" used by Diplock L.J. at p.70 of his judgment in Hong Kong Fir should not be read as requiring the actual use of the word "condition": any term or terms of the contract, which, fairly read, have the effect indicated, are sufficient. Lord Diplock himself has given recognition to this in this House (Photo Production Ltd. v. Securicor Transport Ltd. [I980] A.C. 827, 849). ${ }^{39}$

Lord Roskill, in his speech, also referred to Hongkong Fir and Photo Production, and proposed that Lord Diplock's formulation in the former case should be modified to make it clear that agreement by contracting parties should not be interfered with if it was express or by implication:

Lord Diplock himself in Photo Production Ltd. v. Securicor Transport Ltd. [1980] A.C. 827 at page 849 , speaks of the case where the contracting parties have agreed " whether by " express words or by implication of law" (my emphasis) that " any " (Lord Diplock's emphasis) " failure by one party to perform a particular primary obligation (' condition ' in the nomenclature of the Sale of Goods Act 1893), irrespective of the gravity of the event that has in fact resulted from the breach, shall entitle the other party to elect to put an end to all primary obligations of both parties remaining unperformed ". Thus I think it legitimate to suggest an amendment to the passage in [1962] 2 Q.B. at page 70 either by deleting the word " expressly " or by adding the words "or by necessary implication". 40

Clearly, the House of Lords in Bunge considered that Lord Diplock's formulation in Hongkong Fir was (or should be) limited in its scope, even if it was correct in terms of the specific character of the contract and contractual term that had been at issue in Hongkong Fir. That constrained view of the formulation was further articulated by Lord Scarman, whose speech included a useful summation of the distinction between conditions, warranties and intermediate terms at that time:

In Hong Kong Fir Shipping Co. Ltd. v. Kawasaki K.K. Ltd. [1962] 2 QB 26, the Court of Appeal rediscovered and reaffirmed that English law recognises contractual terms which, upon a true construction of the contract of which they are part, are

\footnotetext{
${ }^{39}$ [1981] UKHL 11, above n38, at 2.

${ }^{40}$ [1981] UKHL 11, above n38, at 11.
} 
neither conditions nor warranties but are, to quote my noble and learned friend Lord Wilberforce's words in Bremer v. Vanden [1978] 2 Lloyd's Rep. 109 at p. 113, "intermediate". A condition is a term, the failure to perform which entitles the other party to treat the contract as at an end. A warranty is a term, breach of which sounds in damages but does not terminate, or entitle the other party to terminate, the contract. An innominate or intermediate term is one, the effect of non performance of which the parties expressly or (as is more usual) impliedly agree will depend upon the nature and the consequences of breach. In the Hong Kong Fir case the term in question provided for the obligation of seaworthiness, breach of which it is well known may be trivial (e.g., one defective rivet) or very serious (e.g., a hole in the bottom of the ship). It is inconceivable that parties when including such a term in their contract could have contemplated or intended (unless they expressly say so) that one defective rivet would entitle the charterer to end the contract or that a hole in the bottom of the ship would not. I read the Hong Kong Fir case as being concerned as much with the construction of the contract as with the consequences and effect of breach. ${ }^{41}$

Addressing the decision in United Scientific, Lord Wilberforce in Bunge refers to the House of Lords in that earlier case having "generally approved" the statement of the relevant law in a footnote to Halsbury's Laws of England, ${ }^{42}$ in asserting:

(1) that the court will require precise compliance with stipulations as to time wherever the circumstances of the case indicate that this would fulfil the intention of the parties, and (2) that broadly speaking time will be considered of the essence in 'mercantile' contracts... ${ }^{43}$

Nonetheless, it might reasonably be said that Lord Wilberforce's view in Bunge was in conflict with the view of Lord Diplock three years beforehand in United Scientific, as that earlier case had its genesis in the landlord's failure to comply with a time clause. Endorsing the House of Lords "inescapable conclusion" in Hongkong Fir that it was not possible to ascertain the character of a condition as to seaworthiness in advance of a breach, Lord Wilberforce said:

Diplock L.J. then generalised this particular consequence into the analysis which has since become classical. The fundamental fallacy of the appellant's argument [that breach of a notice obligation as to time may be "inconsequential", in light of

\footnotetext{
${ }^{41}$ [1981] UKHL 11, above n38, at 3-4.

${ }^{42}$ Halsbury's Laws of England (4th ed) vol 9 (Contract) at [482].

${ }^{43}$ [1981] UKHL 11, above n38, at 2.
} 
Hongkong Fir] lies in attempting to apply this analysis to a time clause such as the present in a mercantile contract, which is totally different in character. As to such a clause there is only one kind of breach possible, namely, to be late, and the questions which have to be asked are, first, what importance have the parties expressly ascribed to this consequence, and secondly, in the absence of expressed agreement, what consequence ought to be attached to it having regard to the contract as a whole. $^{44}$

In any event, although United Scientific firmly established the role of equity in these rent review matters, their Lordships' decision also represented a turning point in the relevant legal analysis. Before United Scientific, and despite Hongkong Fir, successive courts had interpreted the statutory provisions retaining equitable rules in terms of the rules of the common law and equity that prevailed before the Court of Chancery was abolished as a separate court in 1873 (not an entirely fanciful notion given the specific words of section 8 of the Law Amendment Act: "... the same construction and effect as they would have heretofore received in Equity..."), but the House of Lords rejected that approach. According to Lord Diplock, "the waters of the confluent streams of law and equity have surely mingled now", and to speak of the rules of equity being part of the law of England at that time was "about as meaningful as to speak of the Statute of Uses or of Quia Emptores."

In response, Meagher, Heydon \& Leeming (2002) opined that:

Lord Diplock did not explain how equity vanished or what were the consequences of its disappearance. Moreover, when he spoke, Quia Emptores remained in force as a pillar of English real property law. ${ }^{45}$

However, Meagher \& Co could not seriously have believed (surely) that equity, in the form of the body of rules we know as the "rules of equity", the evolution of which was ceased by Act of Parliament in 1873, could continue to hold a meaningful place in our legal system over 100 years later. The concepts yes, but not the rules. We too easily forget that equity, as it was in 1873 , bore no resemblance to the flexible system that it evolved from, whereby the Lord Chancellor could intervene to bring justice to a matter in terms of his own conscience. The flaws and inefficiencies of the rule bound Courts of Chancery, as they were popularly perceived in the middle of the 19th century, were

\footnotetext{
$\overline{{ }^{44} \text { [1981] UKHL 11, above n38, at } 1 .}$

${ }^{45}$ RP Meagher, JD Heydon and MJ Leeming Meagher, Gummow and Lehane's equity, doctrines and remedies (4th ed, Butterworths LexisNexis, Australia, December 2002)
} 
harshly satirized by Charles Dickens (who had himself worked as a law clerk) in his novel Bleak House: ${ }^{46}$

Never can there come fog too thick, never can there come mud and mire too deep, to assort with the groping and floundering condition which this High Court of Chancery, most pestilent of hoary sinners, holds, this day, in the sight of heaven and earth... On such an afternoon, some score of members of the High Court of Chancery bar ought to be-as here they are-mistily engaged in one of the ten thousand stages of an endless cause, tripping one another up on slippery precedents, groping knee-deep in technicalities, running their goat-hair and horse-hair warded heads against walls of words, and making a pretence of equity with serious faces, as players might. ${ }^{47}$

Arguably, the proper role of equity in the world of stare decisis, as it always should have been, is, per Lord Edmund-Davies in Raineri, to "ameliorate the asperities of the common law."48 However, we might go further to say that modern litigants, particularly commercial litigants, expect modern courts to take a commercial perspective - so as to resolve contract disputes in a commercially efficacious manner.

In that vein, in State Trading Corp of India $v$ Golodetz, ${ }^{49}$ Kerr LJ at page 283 concluded:

At the end of the day, if there is no other more specific guide to the correct solution to a particular dispute, the court may have no alternative but to [make] what is in effect a value judgment about the commercial significance of the term in question. ${ }^{50}$

Although the House of Lords subsequently rejected another part of Kerr LJ's decision ("In my view therefore the passage from the judgment of Kerr L.J. in the Golodetz case [1989] 2 Lloyd's Rep. 277, 286, if it was intended to enunciate a general and absolute rule, goes too far." - Lord Steyn in Vitol SA v Norelf Ltd), ${ }^{51}$ the particular passage quoted above from page 283 was cited with approval by the House of Lords in Commerciale Sucres et Denrees $v$ Czarnilow (The Naxos). ${ }^{52}$

\footnotetext{
${ }^{46}$ Charles Dickens Bleak House (Chapman \& Hall Ltd, London, circa 1853).

${ }^{47}$ Dickens, above $\mathrm{n} 46$, at 2.

${ }^{48}$ [1980] 2 ER 145, above n23, at 153.

${ }^{49}$ State Trading Corp of India v Golodetz [1989] 2 Lloyd's Rep 277.

${ }^{50}$ [1989] 2 Lloyd's Rep 277, above n49, at 283.

${ }^{51}$ Vitol SA v Norelf Ltd [1996] AC 800.

${ }^{52}$ Commerciale Sucres et Denrees v Czarnilow (The Naxos) [1990] 1 WLR 1337.
} 
It is worth recalling at this point the words of Bowen LJ, in the 1893 decision in Bentsen $v$ Taylor \& Sons (No. 2): ${ }^{53}$

Of course it is often very difficult to decide as a matter of construction whether a representation which contains a promise, and which can only be explained on the ground that it is in itself a substantive part of the contract, amounts to a condition precedent, or is only a warranty. There is no way of deciding that question except by looking at the contract in the light of the surrounding circumstances, and then making up one's mind whether the intention of the parties, as gathered from the instrument itself, will best be carried out by treating the promise as a warranty sounding only in damages, or as a condition precedent by the failure to perform which the other party is relieved of his liability. ${ }^{54}$

Arguably, as was suggested by Clarke (1991), ${ }^{55}$ the effect of their Lordships' conclusions in United Scientific and The Naxos is that time stipulations are now recognised as being "little different from other stipulations in commercial contracts", an outcome which, notwithstanding other decisions which regarded time stipulations (other than those as to payment - see Seton $v$ Slade ${ }^{56}$ referred to in United Scientific) as conditions precedent, is not wholly at odds with the above words quoted from Bentsen - and it might be said that Lord Diplock in United Scientific merely played up "the light of the surrounding circumstances", in reaching his conclusion that the determination of a new rent (by the landlord in United Scientific) was an event "already accepted" by the tenant as an obligation to the landlord in relation to the relevant rent period.

Clarke identifies, as at 1991, the situations where time will be of the essence in mercantile contracts: ${ }^{57}$

- If time has been held to be of the essence in the same circumstances in the past, although this may be limited to specific circumstances where custom places greater weight on a promise as to time of delivery. Clarke gives the example of promises made by a carrier "about when his ship will be available to the hirer or consignor", such as in The Mihalis Angelos. ${ }^{58}$

\footnotetext{
${ }^{53}$ Bentsen v Taylor \& Sons (No. 2) [1893] 2 QB 274.

${ }^{54}$ [1893] 2 QB 274, above n53, at 281.

${ }^{55}$ Malcolm Clarke "Time and the Essence of Mercantile Contracts: The Law Loses its Way" [1991] CLJ 29.

${ }^{56}$ Seton v Slade (1802) 7 Ves Jun 265.

${ }^{57}$ Clarke, above $\mathrm{n} 55$, at 29 and 31.

${ }^{58}$ The Mihalis Angelos [1971] 1 QB 164.
} 
- If reasonable notice has been given by one party to the other, as to performance of a specific obligation by a specific date - See Stickney $v$ Keeble, ${ }^{59}$ and British Commonwealth v Quadrex. ${ }^{60}$

- Where, per Lord Diplock in United Scientific, ${ }^{61}$ a party's delay beyond the time stipulated in the contract is such as to deprive another party of "substantially the whole benefit which it was intended that he should obtain from the contract."

- If it is necessary for one party to perform its obligation in a timely manner in order for another party to perform its obligation - Per Lord Roskill in Bunge. ${ }^{62}$

- If the contract says that time is of the essence.

This set of 'rules', largely derived from equitable considerations approved since 1873, runs counter to the suggestion of Meagher, Gummow and Lehane, that United Scientific marks the disappearance of equity. Lord Diplock himself refers, in United Scientific, to the rules of equity "to the extent that the Court of Chancery had developed them up to 1873", and it would be unthinkable that the common law should be allowed to continue its evolution, but that equity should be frozen in time forever. As noted by Lord Diplock, the wording of section 41 of the Law of Property Act 1925 placed "no ban upon further development of the rules [of equity] by judicial decision." Accordingly, equity could be adapted to modern needs and experience, as was identified by Lord Lowry in Bunge:

The second general point which I desire to mention concerns stipulations as to time in mercantile contracts, in regard to which it has been said that, broadly speaking, time will be considered to be of the essence. To treat time limits thus means treating them as conditions, and he who would do so must pay respect to the principle enunciated by Roskill L.J., as he then was, in the Hansa Nord case [1976] Q.B. 44, 71A, that contracts are made to be performed and not to be avoided.

The treatment of time limits as conditions in mercantile contracts does not appear to me to be justifiable by any presumption of fact or rule of law, but

${ }^{59}$ Stickney v Keeble [1915] AC 386.

${ }^{60}$ British Commonwealth v Quadrex [1989] 2 All ER 492.

${ }^{61}$ [1978] AC 904, above n25, at 927 (and stated similarly at 931).

${ }^{62}$ [1981] UKHL 11, above n38, at 14. 
rather to be a practical expedient founded on and dictated by the experience of businessmen, just the kind of thing which Bowen L.J. could have had in mind when framing his classic observations on the implied term in The Moorcock (1889) 14 P.D. 64 at p.68...63

A more recent decision of the United Kingdom Court of Appeal, Lancecrest Ltd $v$ Asiwaju, ${ }^{64}$ involved a lease contract where notice to trigger a rent review was not of the essence, but time for the tenant to issue his counter-notice was of the essence. Following United Scientific, the Court of Appeal found that the landlord's late notice of rent review (issued around 54 weeks after the rent review date) was valid, but a failure by the tenant to issue a counter-notice within the time allowed for that counter-notice could not be belatedly remedied. Fortunately for the tenant, a letter challenging the validity of the landlord's notice (sent within the time allowed for a counter-notice, but rejected as such at first instance) was found to be effective as a counter-notice by a majority of the Court of Appeal - undoubtedly influenced by the pragmatic approach adopted in Mannai Investment Co Ltd v Eagle Star Life Assurance Co Ltd, ${ }^{65}$ where Lord Steyn considered that the notices at issue in that case "must be construed taking into account the relevant objective contextual scene."

The Court of Appeal identified that section 41 of the Law of Property Act 1925 "does not mean that a time limit for the taking of a step in a rent review clause, or any other contractual provision, has no effect." It remains effective:

... [in] circumstances... such that the late implementation of the right is barred by estoppel or waiver (albeit that this would require fairly exceptional facts: see Amherst -v- James Walker Goldsmith \& Silversmith Limited (No 2) [1983] Ch $305){ }^{66}$

And, "more importantly".. quoting from Lord Diplock's speech in United Scientific, abridged here:

... so soon as that time has elapsed [the tenant] can give to the landlord notice specifying a period within which he requires the landlord to serve a lessor's notice if he intends the market rent to be determined and payable instead of the former rent

${ }^{63}$ [1981] UKHL 11, above $\mathrm{n} 38$, at 5

${ }^{64}$ Lancecrest Ltd v Asiwaju [2005] EWCA Civ 117, [2005] NPC 21.

${ }^{65}$ Mannai Investment Co Ltd v Eagle Star Life Assurance Co Ltd [1997] AC 749.

${ }^{66}$ [2005] EWCA Civ 117, above n64, at [18]. 
for the ensuing seven years. The period so specified, provided that it is reasonable, will become of the essence of the contract. ${ }^{67}$

The Court of Appeal in Lancecrest clearly enunciates that Lord Diplock's reasoning in United Scientific "is binding on us", and makes no reference to Bunge.

Although Lord Diplock has been a lightning rod for academic criticism of the House of Lords' direction since 1962, his Lordship's central tenet in Hongkong Fir and United Pacific has generally met with judicial approval, in England at least, and, moreover, has been built upon - viz, Oliver LJ in Amherst v James Walker Goldsmith and Silversmith Limited: ${ }^{68}$

I know of no ground for saying that mere delay, however lengthy, destroys the contractual right [that is the right to require a rent review]. It may put the other party in a position where, by taking proper steps, he may become entitled to treat himself as discharged from his obligation; but that does not occur automatically and from the mere passage of time. I know of no authority for the proposition that the effect of construing a time stipulation has not been of the essence is to substitute a fresh implied term that the contract shall be performed within a reasonable time and even if such a term is to be substituted the passage of the reasonable time would not automatically abrogate the contract. ${ }^{69}$

In fact, later in his speech Oliver LJ proposes that 'prejudice' might be abandoned as the yardstick to determine whether a landlord should lose his entitlement to increase the rent in cases of late notice:

I would in fact go further and suggest that, despite what Lord Salmon said in the United Scientific case, even delay plus hardship to the tenants would not disentitle the landlord to exercise the right which he has, on the true construction of the contract, unless the combination amounted to an estoppel. ${ }^{70}$

${ }^{67}$ [2005] EWCA Civ 117 at [18] referring to [1978] AC 904 at 933G-934A.

${ }^{68}$ Amherst v James Walker Goldsmith and Silversmith Limited [1983] 2 All ER 1067, [1983] 1 CJ 305.

${ }^{69}$ [1983] 2 All ER 1067, above n68, at 1073.

${ }^{70}[1983] 2$ All ER 1067, above n68, at 1074. 


\section{New Zealand Without Section 9 of the Insurance Law Reform Act 1977}

\section{A United Scientific and Amherst in New Zealand}

In Masfen $v$ de France, ${ }^{71}$ and Frater Williams \& Co Ltd $v$ Australian Guarantee Corporation (NZ) Ltd, ${ }^{72}$ the High Court of New Zealand and the Court of Appeal respectively determined that, because time was not generally of the essence in relation to rent review cases, the landlords were free to give late notice. These cases involved relatively modest delays. The High Court followed Amherst. In the Court of Appeal, only Gault $\mathbf{J}$ referred to Amherst.

However, in Tournament Parking Limited $v$ The Wellington Company Limited, ${ }^{73}$ the High Court very recently considered a landlord's significant delay (15 years in relation to the earliest period) in triggering rent reviews that were permitted every three years under the lease. In view of the respondent's refusal to pay the increased rents, the appellant had issued notice purporting to terminate the lease. At first instance, the District Court found, "contrary to the usual presumption", that time was of the essence, preventing the landlord from reviewing the past periods.

In considering the nature of a rent review, Miller $\mathrm{J}$ in the High Court noted that:

The lessee gains a benefit for which it did not bargain when through some oversight the lessor fails to review the rent. For that reason, a presumption that time is not of the essence of a rent review clause applies in favour of the lessor even if a review can only result in the rent rising. The presumption is ordinarily efficient, at least in the case where delay imposes no additional costs on the lessee, in the sense that contract law serves economic efficiency by holding the parties to their bargain, reducing the risks inherent in exchanging promises about future performance. ${ }^{74}$

However, despite his Honour's acknowledgment that the tenant may benefit from rent reviews being done punctually (assuming they are to be done), in terms of cashflow and the tenant's ability to pass the increased rent on to relevant third parties - subtenants and customers - he nonetheless found that displacing the presumption (that time is not of the essence) requires that the contract "expressly provides that time is of the essence or...

${ }^{71}$ Masfen v de France (1989) 1 NZ ConvC 190,179 (HC).

${ }^{72}$ Frater Williams \& Co Ltd v Australian Guarantee Corporation (NZ) Ltd (1995) ANZ ConvR 247.

${ }^{73}$ Tournament Parking Limited $v$ The Wellington Company Limited [2010] NZHC 1096.

${ }^{74}$ [2010] NZHC 1096, above n73, at [33]. 
[that the parties' intention in that regard be] gleaned from the language of the lease and the commercial context." 75

His Honour earlier records that United Scientific and Amherst were followed in New Zealand in Wing Crawford Holdings $v$ Lion Corporation Ltd, ${ }^{76}$ where the rent review clause "stipulated that the rent shall be reviewed at 30 month intervals, with the new rent to be agreed upon and determined by arbitration if necessary." His Honour further records that, in Wing Crawford, Chilwell $\mathrm{J}$ had cited Amherst in support of the proposition that "delay plus hardship to the tenant will not disentitle the landlord from exercising his contractual right to have the rent reviewed unless the circumstances amount to an estoppel."77

\section{B What About Time Limits in New Zealand Contracts of Insurance?}

Turning now to the matter of insurance contracts in New Zealand, it might reasonably be said that, in view of Section 7(4)(a) of the Contractual Remedies Act, an express or implied agreement that time is of the essence may lead to a right to cancel, which would not be overcome by Section 90 of the Judicature Act. However, the more typical problem with a contract of insurance is the late notification of claims, and the consequent disputes as to whether the insurer is nonetheless liable.

It seems likely now, if the performance of a term as to time is not expressly or impliedly essential, that equity (in the guise of Section 90) may intrude. The relevant tension between law and equity is evident in the words from Lord Justice Oliver, cited above, specifically:

[Mere delay] may put the other party in a position where, by taking proper steps, he may become entitled to treat himself as discharged from his obligation but that does not occur automatically and from the mere passage of time. ${ }^{78}$

In relation to rent cases, the context is a contract which specifies not only a time limit for notice of rent review, but which inevitably identifies the point of time when the landlord's entitlement to enjoy such a review may arise. While (as per Lord Salmon in United

${ }^{75}$ [2010] NZHC 1096, above n73, at [44].

${ }^{76}$ Wing Crawford Holdings v Lion Corporation Ltd [1989] 1 NZLR 562.

77 [2010] NZHC 1096, above n73, at [40].

${ }^{78}$ [1983] 2 All ER 1067, above n68, at 1073. 
Scientific) an inordinate delay occasioning "prejudice or hardship" to the tenant may extinguish the landlord's right to a review in circumstances of delay, ${ }^{79}$ which is analogous to estoppel, in other circumstances the tenant cannot complain that he had no warning that a rent review was anticipated, and can avail himself or herself of the right, in New Zealand at least, to issue a "time is of the essence" notice to a landlord who has failed to trigger a rent review.

Insurers, on the other hand, do not have the benefit of the tenant's knowledge - the fortuity of loss means that inherently the insurer has no basis to expect a claim in any particular policy year. Most policies are claim free in most years. Quoting again from Martin (2005): ${ }^{80}$

... periodic review of the rent is such an important part of the original bargain between landlord and tenant that those parties cannot be supposed to have intended that the right to that review should be lost merely because of failure to take a particular step in time.

While it might be said that payment of claims is a similarly important part of the bargain between insurers and policyholders, the question of prejudice looms larger. Even so, the question becomes whether equity should allow insurers to impose time limits for claim notification, when such limits are inherently arbitrary, and thereby (subject to the operation of other legal rules) deprive legitimate claimants of their indemnity solely due to failure to meet a relevant time limit - is timely notification of claims such a significant aspect of insurers risk management that prejudice should be inferred?

Harking back to United Scientific, it is relevant here that Lord Diplock did not see prejudice to a tenant arising from late notice of rent review where "postponement of that event beyond the time stipulated in the contract is not so prolonged as to deprive the obligor of substantially the whole benefit that it was intended he should obtain by accepting the obligation." 81

\section{Lord Diplock went on to say:}

The absence of any serious detriment to the tenant if the determination of the new rent is postponed until some time after the commencement of the 10 year period to

\footnotetext{
${ }^{79}$ [1978] AC 904, above n25, at 956.

${ }^{80}$ Martin, above $\mathrm{n} 26$, at 2.

${ }^{81}$ [1978] AC 904, above n25, at 931.
} 
which it will relate is to be contrasted with the detriment to the landlord if strict adherence to the date specified in the review clause is to be treated as of the essence of the contract. If it were determined even slightly late the landlord would lose his right to the additional rent for the whole period of 10 years until the next review date. $^{82}$

This is, surely, the position in relation to contracts of insurance. A modest delay in claim notification is, in most cases, unlikely to involve any detriment to the insurer, whereas the policyholder risks losing his right to the whole thing which (for him or her) the policy is about.

In the United Kingdom at least, the decisions in Hongkong Fir and United Scientific have been found to be relevant to insurance claims. For example, in Alfred McAlpine Plc v BAI (Run-Off) $L t d,{ }^{83}$ the Court considered whether a breach of an insurance policy's notice provision was sufficiently serious to permit the insurer to decline the claim - the underlying premise was that the relevant notice provision was an intermediate term. Lord Justice Waller referred to the insured accepting a bargain with the insurer whereby the insured's failure "in a serious way" to give the required notice might relieve the insurer of its obligation to pay a claim. ${ }^{84}$ Similarly, in Glencore International AG $v$ Ryan (The Beursgracht), ${ }^{85}$ underwriters sought to escape liability in relation to a vessel that was declared for insurance under an open cover charterer's liability policy. While accepting that such declarations were subject to an implied term requiring them to be made within a reasonable time, the Court regarded the implied term as intermediate, and the breach as not so serious as to prejudice the underwriters. ${ }^{86}$

In Jacobs $v$ Foster, ${ }^{87}$ as noted in chapter I of this dissertation, the Court of Appeal found that the insured was not in breach of an obligation to give immediate notice of circumstances "likely" to give rise to a claim, when a customer was injured after slipping on diesel fuel spilt on the forecourt of the insured's petrol filling business... the Court's "objective test" (based ostensibly on the lack of evidence to show that the insured knew of anything being wrong with the forecourt) appears to have been somewhat influenced by the assessment that the nature of the victim's injuries was not such that she was more likely than not to make a claim, demonstrating a reluctance to concede that society had

\footnotetext{
${ }^{82}$ [1978] AC 904, above n25, at 932.

${ }^{83}$ Alfred McAlpine Plc v BAI (Run-Off) Ltd [2000] 1 Lloyd's Rep 437.

${ }^{84}$ [2000] 1 Lloyd's Rep 437, above n83, at 444.

${ }^{85}$ Glencore International AG v Ryan (The Beursgracht) [2002] 1 Lloyd's Rep 574.

${ }^{86}$ [2002] 1 Lloyd's Rep 574, above n85, at 581.

${ }^{87}$ Jacobs v Foster [2000] Lloyds Rep 506.
} 
reached "such a sorry state" that it should be assumed that such victims would make a claim.

In Friends Provident Life \& Pensions Ltd $v$ Sirius International Insurance, ${ }^{88}$ where a claim was notified to the underwriters of a claims made liability policy after the end of the policy period, the terms of the policy also required that certain claims "be notified immediately by the assured in writing to the Underwriters hereon." The assured was the plaintiff, and the insurer sought to defend the matter on the dual basis that the claim was not notified immediately, and was in any event notified outside the policy period. Waller LJ, following his own position in McAlpine, could see "no difficulty in construing a notice provision as being an innominate term which provides the insurer with a right to reject the claim if there is a breach of sufficient gravity ie a breach which has seriously prejudiced the insurer." ${ }^{19}$ Although, conceptually, Waller LJ took the view that the insurer's obligation to pay a claim was severable, and thereby subject to the "suspensive effect" of the notice requirement, this does not prevent the "application of the contract" concept (per Hongkong Fir) being applied to the specific event corresponding to the insurer's severed obligation.

The significant change here, evidenced by these insurance cases, and flowing principally from Hongkong Fir and United Scientific, is the treatment of certain contract conditions as contractual promises rather than conditions precedent. Notice provisions in insurance contracts have traditionally been treated as conditions precedent, ${ }^{90}$ but the conceptual analysis in Hongkong Fir, McAlpine and Friends Provident would appear to have changed their classification. The fact that Hongkong Fir was dealing with 'termination' of contact is tidily addressed by Carter, Tolhurst \& Peden (2006):

It is, in any event, a little misleading to state a general principle in terms that the Hongkong Fir doctrine applies only if the 'whole' contract is terminated. It is of the very essence of discharge for breach that only the executory part of the contract is 'terminated'. The proper statement of termination is that the obligation of the parties to perform or to be ready and willing to perform unperformed obligations is discharged. It is only where the contract is wholly executory that the doctrine applies to the whole contract. Nevertheless, it is correct to say both that in order to justify termination the breach must have a very serious impact on the promisee and that the

\footnotetext{
${ }^{88}$ Friends Provident Life \& Pensions Ltd v Sirius International Insurance [2005] 2 Lloyd's Rep 517.

${ }^{89}$ [2005] 2 Lloyd's Rep 517, above n88, at 532.

${ }^{90}$ See Kenneth Sutton Insurance Law in Australia (3rd ed, LBC, Sydney, 1999) at [15.26].
} 
promisee cannot 'pick and choose', that is, seek to terminate part but not all of the executory obligations to which the breach relates. ${ }^{91}$

Referring to Waller J's judgment in Friends Provident Life, Carter, Tolhurst and Peden suggest that "the circumstances of the recent cases on insurance contracts are sufficiently analogous to cases such as Bremer $v$ Vanden and United Scientific to say that Waller LJ's conclusions are supported by those decisions of the House of Lords." In other words, Bremer and United Scientific may be regarded as authorities for the notion that, conceptually at least, an insurer's right to reject a claim on the basis of a policyholder's breach rests on whether the breach was of "sufficient gravity", for example whether the breach has "seriously prejudiced the insurer."

The rent review cases show that New Zealand has adopted the line of reasoning flowing from United Scientific and Amherst. In the United Kingdom, that same line of reasoning has, in relation to insurance cases (for example, Glencore and Friends Provident) had a similar effect to section 9 of New Zealand's Insurance Law Reform Act 1977 - also see Appendix 1, and Chapter VI of this dissertation. It follows, I suggest, that section 9 may now be redundant, at least in relation to some claims. A policyholder whose claim is denied on the basis of late notice might, as the law presently stands, be able to bring a successful action under section 90 of the Judicature Act 1908 - without reference to section 9 .

However, the existence of section 9 of the Insurance Law Reform Act explains the lack of insurance decisions referring to section 90 of the Judicature Act. As to whether section 9 can be dispensed with in practice, we might reasonably be concerned about certainty at this stage, section 9 provides certainty, whereas a similar application to the Court founded on section 90 may or may not result in a similar outcome. Nonetheless, as the basis for an alternative cause of action, section 90 deserves attention. Perhaps the more recent rent review cases will encourage insurance claim litigants to craft 'in the alternative' pleadings accordingly.

\footnotetext{
${ }^{91}$ JW Carter, GJ Tolhurst and Elisabeth Peden " Developing the Intermediate Term Concept" (Journal of Contract Law, 2006) 268 at 279 .
} 


\section{$V \quad$ The Australian Experience}

As noted earlier, Australia has both an equivalent to New Zealand's section 9 - contained in section 54 of the Insurance Contracts Act (Cth) - and a statutory deeming regime arising from section 40 of the same Act. This chapter considers the interplay between sections 54 and 40 of the Australian legislation, and reviews relevant judgments. However, I first start, building on the earlier discussion about the preservation of equity and the English cases which have followed Hongkong Fir, with a review of the Australian adoption of Lord Diplock's formulation.

\section{A United Scientific and Amherst in Australia}

The concept of 'intermediate' or 'innominate' terms was approved by the High Court of Australia in Ankar Pty Ltd v National Westminster Finance (Australia) Ltd, ${ }^{92}$ where Lord Diplock's creation in Hongkong Fir was praised as having brought "a greater flexibility to the law of contract". 93 However, the High Court also noted that Lord Wilberforce had suggested in Bunge that (as quoted in Ankar) "a time clause is not susceptible of treatment as an innominate clause because it can give rise to one kind of breach only - to be late." The High Court didn't need to address this suggestion, so it remained unresolved at that time.

There is no mention of United Scientific in Ankar, but Ankar was not a rent review case, or a case involving a party's failure to give timely notice. In any event, in view of the final basis for the High Court's determination in Ankar, Hongkong Fir was only relevant to the extent of Lord Diplock's focus on contractual interpretation in the context of the whole bargain. The dispute in Ankar arose from the respondent's breaches of a Security Deposit Agreement between the parties, and the appellant's contention that, as these (in the appellant's view) were breaches of essential conditions, the appellant was discharged from future liability as surety. The High Court determined that the relevant conditions were indeed essential:

... the failure to notify Ankar of Manufacturing's default (cl.8) and intended assignment (cl.9) precluded the circumstances existing in which Ankar could enjoy the agreed opportunity of attempting to avoid the very situation which it was

\footnotetext{
${ }_{92}$ Ankar Pty Ltd v National Westminster Finance (Australia) Ltd [1987] HCA 15, (1987) 162 CLR 549, 70 ALR 641.

${ }^{93}$ [1987] HCA 15, above n92, at [22].
} 
obviously most concerned to avoid, namely, the situation in which it would be liable as surety for a lessee of equipment who remained liable to pay the rent for the equipment but no longer enjoyed the quid pro quo of possession of it. ${ }^{94}$

Although this decision involved the application of a "special rule which reflects a common law approach to sureties", the High Court's apparent approval of United Scientific was at the least a toe in the door, in Australia, in relation to Lord Diplock's new formulation.

Subsequently, in Louinder v Leis, ${ }^{95}$ Mason J, adopting Lord Diplock's position in United Scientific regarding the consequences of breaching a non-essential term, considered that:

... delay beyond the stipulated date will give rise to a liability in damages. But because equity treats the time stipulation as non-essential, mere breach of it does not justify rescission by the innocent party... 96

The following year, the High Court considered, in Gollin \& Co Ltd v Karenlee Nominees Pty $L t d,{ }^{97}$ whether the failure to appoint a valuer within a reasonable time - as required in the parties' contract - was a breach of an essential term. Again relying on United Scientific, the High Court found that:

... even if the lease had contained a provision expressly requiring Gollin and the lessors respectively to appoint a valuer or to activate the rent review procedure within a specific time, the performance of that obligation within that particular time could not, without more, have properly been seen either as a condition of the applicability of cl. III(vii) or as being of the essence of the contract. ${ }^{98}$

However, not all members of the High Court of Australia have been enthusiastic about the adoption of the concepts established through Hongkong Fir and United Scientific. In his 2008 lecture honouring Tony Lee, Michael Kirby, a former Australian High Court Judge, described another eminent jurist, Lord Denning, as "probably... the runner-up to Lord Diplock as chief barbarian" in relation to this merger of law and equity. Kirby refers

\footnotetext{
${ }^{94}$ [1987] HCA 15, above n92, at [15].

${ }^{95}$ Louinder v Leis [1982] HCA 28, (1982) 149 CLR 509.

${ }^{96}$ [1982] HCA 28, above n95, at [34].

${ }^{97}$ Gollin \& Co Ltd v Karenlee Nominees Pty Ltd [1983] HCA 38, (1983) 153 CLR 455.

${ }^{98}$ [1983] HCA 38, above n97, at [17].
} 
to Lord Denning's speech in Central London Property Trust Ltd v High Trees House Ltd, where his Lordship said that:

At this time of day it is not helpful to try to draw a distinction between law and equity. They have been joined together now for over seventy years, and the problems have to be approached in a combined sense. ${ }^{99}$

This sentiment has been clearly evident in decisions of the New Zealand Court of Appeal at least since the tenure of President Cooke, as Kirby himself records as an introduction to this further extract from Meagher, Gummow and Lehane:

The prospect of any principled development of equitable principles seems remote short of a revolution on the Court of Appeal. The blame is largely attributable to Lord Cooke's misguided endeavours. That one man could, in a few years, cause such destruction exposes the fragility of contemporary legal systems and the need for vigilant exposure and rooting out of error.

That Australia is at a different stage of development in relation to the fusion of law and equity is not in dispute. Kirby identifies some of the reason for this:

If in Australia the process of harmonisation has taken longer, this was doubtless because of the delay (particularly in New South Wales) in adopting the principles of the Judicature Acts and in enacting legislative instructions to the courts, where applicable, to reconcile the great traditions of the common law and equity law. It is not for equity lawyers, or anyone else, to defy such statutory instructions. Nor for them to set out to frustrate the whole-hearted achievement inherent in this change. Yet, to some extent, that is what has happened in Australia. Loyalty to, and appreciation for, equity has become, on occasion, an impediment to proper harmonisation and rationalisation of the whole body of the law. It is an impediment that is simply wrong in legal principle.

Perhaps delayed development (for want of a better description of it) has impacted in the area - for example - of exemplary damages, but, notwithstanding Kirby's disapproval, the Australian courts appear to have been infected by those "barbarian" notions of the House of Lords in relation to rent reviews. In GR Mailman and Associates $v$ Wormald (Australia) Pty Limited, ${ }^{100}$ Chief Justice Gleeson observed that:

\footnotetext{
${ }^{99}$ Central London Property Trust Ltd v High Trees House Ltd [1956] 1 All ER 256 at 259.

${ }^{100}$ GR Mailman and Associates $v$ Wormald (Australia) Pty Limited (1991) 24 NSWLR 80.
} 
The decision in United Scientific Holdings Ltd v Burnley Borough Council was, and was expressed to be, a judicial response to a practical commercial problem relating to the fixing of the rental for leases, and especially long leases, in times of inflation. The expectation of inflation and the probability of variations in the rates at which it will occur, make it commercially impractical in many cases for the parties to a lease to agree upon a single figure which will be an acceptable rent for the whole of the term of the lease. To overcome this difficulty they commonly establish a machinery for rent review at various stages during the term of the lease, the substantial object of the machinery usually being to ascertain the current market rent for the subject premises and to make that the operative rent. The market rent may be established by agreement, or in default of agreement, by some procedure for dispute resolution.

A decade later, in Jacques Nominees Pty Limited $v$ National Mutual Trustees Ltd, ${ }^{101}$ MacNamara DP, although having emphasised the prejudice 'rule' underpinning equity's approach to delay (citing Lord Salmon in United Scientific: "any unreasonable delay caused by the landlords and which is to the tenants' prejudice would prevent the rent being revised after the review date"), ${ }^{102}$ nonetheless approved the comments of Oliver LJ in Amherst. ${ }^{103}$

Significantly, none of these cases involved notification delays in relation to insurance claims.

\section{B Insurance Contract Law in Australia in 1975}

In his 2010 lecture at the Australian Insurance Law Association National Conference, Michael Kirby described Australian Insurance Contract Law in 1975 - at the time when he became Chairman of the Australian Law Reform Commission - as "a gorgonzola."104

More specifically, he identified sources of confusion and uncertainty:

\footnotetext{
${ }_{101}$ Jacques Nominees Pty Limited v National Mutual Trustees Ltd [2001] VCAT 657.

${ }^{102}$ [1978] AC 904, above n25, at 951.

${ }^{103}$ [1983] 1 CJ 305, above n68, at 315.

104 "a sharp-flavoured blue-veined Italian cheese, [named after] Gorgonzola, Italian town where it originated", per Collins English Dictionary (United Kingdom, definition downloaded 18 September 2011) HarperCollins Publishers Ltd $<$ www.collinslanguage.com>.
} 
Insurance contracts were subject to a bewildering variety of laws. They included the Common law and the Statutes of the Imperial, State and Federal Parliaments. The Common law was, frequently, antiquated. Many of the principles adopted in Australia were (except for minor variations) identical with those developed in the United Kingdom. Issues specific to the Australian experience had never really been addressed systematically, still less nationally. There were significant gaps in the coherence of the governing law. Additionally, a few of the Imperial Acts still applied in Australia. They were generally expressed in archaic and obscure language. Often they addressed problems of a by-gone era. They largely ignored then current problems of then widespread consumer insurance. State law had been piecemeal and sporadic, often limited to particular types of transactions while attempting to deal with specific insurance problems.

One such problem was the fact of an insurance company's common law right to include a term of contract whereby a claim may be refused if it is not notified to the insurer within a specified time. Joske and Brooking (1975) ${ }^{105}$ describe the logical basis for a term of a policy of insurance against theft, requiring the insured to give notice of claim within seven days of the incident occurring:

The object of such a provision clearly is to achieve the prompt supply of information in order to verify allegations of theft and to give opportunity for the recovery of stolen goods. ${ }^{106}$

However, what is a reasonable time? Seven days? 20 days? 200 days? It might be argued that the best opportunity for the recovery of stolen goods lies within hours of the theft, and so perhaps a time limitation in a theft policy should reflect that. However, this underscores the arbitrary nature of such time limitations, which must necessarily balance the insurer's wish to assess a claim promptly, against the practical reality that not all claims need or deserve that kind of priority.

It was undoubtedly to address the unfairness which often arises from such time limitations, that the Parliament of Victoria, Australia, enacted in 1958 Section 27 of the Instruments Act of that year:

If by reason of accident, mistake or other reasonable cause any insured fails to give any notice or make any claim in the manner and within the time required by the contract of insurance such failure shall not be a bar to the maintenance of any

\footnotetext{
${ }^{105}$ PE Joske and Robert Brooking Insurance Law in Australia and New Zealand (Butterworths, Sydney, 1975).

${ }^{106}$ Joske and Brooking, above n105, at 44.
} 
proceedings (whether legal proceedings or arbitration proceedings) upon the contract by the insured unless the court or the arbitrator or umpire (as the case may be) considers that the insurer has been so prejudiced by such failure that it would be inequitable if such failure were not a bar to the maintenance of such proceedings.

Joske and Brooking comment on that 1958 provision as follows:

Whether the insurer is prejudiced by the failure to give notice can be judged only by a consideration of all the facts of each case. The sort of case that would seem to be contemplated is where the facts are such that a reasonable insurer would wish to investigate them and where, owing to the notice or claim not having been given or made, it has become too late to investigate them. ${ }^{107}$

It does not appear that, at that stage (1958 to 1974) any other State of Australia had a similar provision in force. However, in 1975 the State of New South Wales passed into law section 18 of the Insurance Act 1902 (NSW), ${ }^{108}$ which permitted a court to excuse a policy holder's failure to observe or perform a term or condition of an insurance policy where that failure did not prejudice the insurer. Introducing the bill into the NSW Parliament, the Minister for Justice of that day made the following observations about the intent behind the new Section 18:

It is designed, of course, to prevent advantage being taken of a mere technicality. One ready illustration of the operation of the provision is where a person who has held a driver's licence for many years has by oversight neglected for a few days to renew his driver's licence and during that short period is involved in a collision for which he is in no way responsible. Under the strict terms of his policy his indemnity can be withheld as he is in breach of the condition that the vehicle must be driven by a licensed driver, but it could not be suggested that the insurance company is in any way prejudiced in such a case. ${ }^{109}$

The NSW provision did, of course, extend to terms or conditions of insurance policies that purported to impose a time limitation for giving notice of claim.

Sutton (1999), ${ }^{110}$ referring to McPherson \& Davies Shopfitters Pty Ltd v Mercantile Mutual Insurance Co Ltd, ${ }^{111}$ and Morlea Professional Services Pty Ltd v South British

${ }^{107}$ Joske and Brooking, above n105, at 45.

${ }^{108}$ By way of section 6 of the Commercial Transactions (Miscellaneous Provisions) Act 1975 (NSW).

${ }^{109}$ [1974] Parliamentary Debates (NSW) at 1705.

${ }^{110}$ Kenneth Sutton Insurance Law in Australia (3rd ed, LBC, Sydney, 1999). 
Insurance Co Ltd, ${ }^{112}$ says that while the overall onus of proof under section 18 rests with the claimant, an insurer who asserts prejudice has the onus to prove that prejudice which "must be real and not speculative." ${ }^{113}$

\section{Post 1975... Australian Insurers Caught Unawares}

A significant focus of the Australian Law Reform Commission's attention between 1975 and 1984 was the parlous state of insurance contracts law in Australia. While Victoria and New South Wales had addressed certain issues, by and large the insurance contracts legislation in most states was deficient and inconsistent with the consumer-centric emphasis adopted in other areas of the law. In 1975, the Federal Government had passed into law the Family Law Act, which effectively replaced a myriad of state law relating to family property and child custody (but not child welfare, which remained with the State jurisdictions). This represented a successful transfer of power from the States to the Commonwealth, and undoubtedly encouraged the inter-state co-operation that led to the Insurance Contracts Act 1984.

\section{Insurance Contracts Act}

This legislation came into force on 1 January 1986.

As we have seen earlier, both claims made, and claims made and notified policies may optionally include, coupled with a deeming provision, some form of 'notification of circumstances' clause which allows an insured to give notice of relevant circumstances to the insurer within the policy period or such further period as is allowed (however, it is important to note that some policies may require the notice, but not include the deeming provision). The end of the policy period is usually the time limit for invoking a deeming provision. Prior to 1 January 1986, insurers could generally rely on the effectiveness of the notice requirements associated with deeming provisions. Although section 27 of the Instruments Act 1958 (Vic), or section 18 of the Insurance Act 1902 (NSW) might, with hindsight, have founded a challenge to an insurer's entitlement to rely on such notice requirements in some circumstances, it does not appear that possibility was tested in

\footnotetext{
${ }^{111}$ McPherson \& Davies Shopfitters Pty Ltd v Mercantile Mutual Insurance Co Ltd NSWSC, 26 June 1986, per Wood J.

${ }^{112}$ Morlea Professional Services Pty Ltd v South British Insurance Co Ltd NSWSC, 2 June 1986, per Clarke J.

${ }^{113}$ Sutton, above $\mathrm{n} 110$, at 1079 .
} 
relation to claims made policies. However, section 54 of the new Insurance Contracts Act was to eventually change the rules in a way that insurers apparently did not anticipate.

Section 54 of the Insurance Contracts Act is the Australian equivalent of section 9 of New Zealand's Insurance Law Reform Act 1977, although there is a significant difference in practice, in relation to prejudice, as we will see later.

Section 54 of the Insurance Contracts Act, set out in full in Appendix 1 of this dissertation, includes the following (consolidated):

Subject to this section, where the effect of a contract of insurance would, but for this section, be that the insurer may refuse to pay a claim, either in whole or in part, by reason of some act [or omission] of the insured or of some other person, being an act [or omission] that occurred after the contract was entered into but not being an act [or omission] in respect of which subsection (2) applies, the insurer may not refuse to pay the claim by reason only of that act [or omission] but the insurer's liability in respect of the claim is reduced by the amount that fairly represents the extent to which the insurer's interests were prejudiced as a result of that act [or omission].

So, just because an insured has failed to meet a specified deadline for notifying or lodging a claim (or, as in the case of QBE's motor vehicle policy quoted in Chapter II of this dissertation, has failed to provide notification "as soon as possible"), that alone does not entitle the insurer to decline the claim.

If the policy was issued on a claims made and notified basis, and the third party's claim was received by the insured during the policy period, then the claim is payable regardless of when the insured gave notice in writing to the insurer of the claim or the relevant facts - the effect of section 54 is that late notification to the insurer is excused - although the insurer's liability in respect of the claim may be reduced by the amount that fairly represents the extent to which the insurer's interests are prejudiced by the late notification.

However, despite the fact that the lack of a deeming provision could lead to a policyholder being bereft of cover, ${ }^{114}$ awareness of the need for deeming provisions was not universal, and the specific terms of them varied greatly between insurers. To address this situation, the Insurance Contracts Act includes, in section 40, a statutory extension of

${ }^{114}$ For example, MAF in QBE Insurance Ltd v Attorney General [2005] NZCA 193. 
cover whereby notification of circumstances that may lead to a claim is deemed to be notification of a claim.

The relevant parts of section 40 read as follows: ${ }^{115}$

This section applies in relation to a contract of liability insurance the effect of which is that the insurer's liability is excluded or limited by reason that notice of a claim against the insured in respect of a loss suffered by some other person is not given to the insurer before the expiration of the period of the insurance cover provided by the contract.

Where the insured gave notice in writing to the insurer of facts that might give rise to a claim against the insured as soon as was reasonably practicable after the insured became aware of those facts but before the insurance cover provided by the contract expired, the insurer is not relieved of liability under the contract in respect of the claim, when made, by reason only that it was made after the expiration of the period of the insurance cover provided by the contract.

In simple terms, section 40 means that a late claim must be paid (if it is otherwise covered by the policy) so long as, before the policy period ended, the insured gave notice to the insurer including the relevant facts. This is, in effect, a statutory deeming provision in relation to circumstances notified during the policy period.

Therefore, if a policy is issued without a contractual deeming provision, and the third party's claim is not received by the insured during the policy period, then the claim is only payable against the policy for that period where, pursuant to section 40 , the insured notified the insurer of the relevant facts "as soon as was reasonably practicable after the insured became aware of those facts but before the insurance cover provided by the contract expired..." In the absence of such notice, section 54 would not apply either, because the trigger event - receipt of the claim by the insured - has not occurred, and so the question of late notification to the insurer does not arise.

Where a policy includes a contractual deeming provision, it is now well established that section 54 of the Insurance Contracts Act may overcome any time limitation in that provision - so that a late notification is held to be a valid notification - thereby bringing the subsequent (and late) claim into the policy period. The upshot of this, it seems, has been the progressive removal of these deeming provisions, by insurers, assisted by the

${ }^{115}$ See Appendix 1 for the full text of section 40. 
fact that section 40(3) of the Act enables an insured to give notice of relevant circumstances anyway, so long as such notice is within the policy period. ${ }^{116}$

Kirby (2010) ${ }^{117}$ records that the Australian Law Reforms Commission's initial views, regarding the "balance to be struck" between industry stakeholders and the community, were published in a discussion paper in 1979. That paper was followed by public hearings and seminars, before a final report (ALRC 20) was tabled in the Australian Federal Parliament on 14 December $1982 .^{118}$ Most of the public focus, according to Kirby, was on the issues of fraud, non-disclosure and good faith. The terms of section 54 do not appear to have attracted much controversy at the time.

On the face of it, section 54 appears reasonable and logical - why should an insurer, in the absence of prejudice, be allowed to decline a claim merely on account of delayed notification. Even if there is prejudice, the extent of it can be ascertained, and deducted from the claim payout. The policyholder bears only the amount (in addition to any excess or other deductible) that corresponds to the insurer's increased costs or other prejudice arising from the late notification of the claim.

Moreover, at least in Victoria and New South Wales, Australia's two largest states, the general principle reflected in section 54 was already part of the law. ${ }^{119}$

However, the insurers had failed to turn their collective mind to the matter of contractual deeming provisions in claims made insurance policies. Such provisions reflect the uncertainty that often exists when a policyholder has notice of circumstances that may result in a claim, but is not in a position to formally notify the insurer of the claim. Without the benefit of a deeming provision, whereby notice of relevant circumstances is deemed to be notice of the claim, policyholders faced (before section 40 of the Insurance Contracts Act was enacted) the possibility of being required by their policy terms to notify the insurer of relevant circumstances, but of then being denied indemnity due to the claim itself being received in a later policy year, by which time the policy may have lapsed, or, worse still, may have been cancelled by the insurer in view of the potential claim. Deeming conditions included, as they must, a limitation as to time for notice. Prior

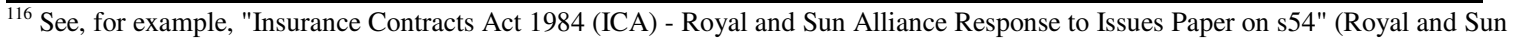
Alliance Insurance Australia Limited, Australia, 16 October 2003).

${ }^{117}$ Michael Kirby, Retired Justice of the High Court of Australia "Australian Insurance Contract Law: Out of the Chaos - A Modern, Just and Proportionate Reforming Statute" (Hugh Rowell Memorial Lecture, Australian Insurance Law Association National Conference, Adelaide, Australia, 28 October 2010).

${ }^{118}$ The Law Reform Commission Insurance Contracts (Report No 20, Australian Government Publishing Service, Canberra, 1982).

${ }^{119}$ Instruments Act 1958 (VIC), section 27. Insurance Act 1902 (NSW), section 18.
} 
to section 54 of the Insurance Contracts Act being enacted, an insurer could enforce that limitation as to time (treating it as a condition precedent), even if the insurer was not prejudiced in a particular case. After section 54 was enacted, late notification only had consequences for the policyholder if the insurer could show prejudice.

\section{Australian Hospital Care}

Despite the clear terms of section 54, it was to be several years (nearly 15 years in fact) before the High Court of Australia issued its landmark decision in FAI General Insurance Co Ltd v Australian Hospital Care Pty Ltd, ${ }^{120}$ confirming the intention that section 54 would apply to all claims including those arising under claims made policies.

The dispute that led to Australian Hospital Care arose after a patient at the Pindara Private Hospital (a facility owned by Australian Hospital Care) complained regarding his treatment at that hospital in 1991. However, Australian Hospital Care failed to notify its insurers at the time, FAI. Subsequently, with effect from 20 June 1992, Australian Hospital Care took out new insurance through Lloyds Underwriters. Then, in December 1992, the patient brought his claim against the hospital and its surgeon. The Lloyds Underwriters declined the claim on the basis that it arose from circumstances known to Australian Hospital Care before 20 June 1992. FAI declined the claim on the basis that Australian Hospital Care had failed to notify FAI of the relevant circumstances during the policy year when the possibility of a claim arose.

McHugh, Gummow and Hayne JJ identified the key issue for the Court as being:

... what operation s 54 of the Insurance Contracts Act 1984 (Cth) has in the events that have happened. In particular, does s 54(1) preclude the insurer from refusing to pay the insured's claim on the ground that the insured omitted to give to the insurer, within the period of cover, notice of an occurrence which may give rise to a claim? ${ }^{121}$

Their Honours acknowledged the reasons why insurers issue claims made policies for certain risks, as discussed by McLachlin J in Reid Crowther \& Partners Ltd $v$ Simcoe \& Erie General Insurance $\mathrm{Co},{ }^{122}$ summarised here:

\footnotetext{
${ }^{120}$ FAI General Insurance Co Ltd v Australian Hospital Care Pty Ltd [2001] HCA 38, (2001) 11 ANZ Ins Cas I[61-497.

${ }^{121}$ [2001] HCA 38, above n120, at [18].

${ }^{122}$ Reid Crowther \& Partners Ltd v Simcoe \& Erie General Insurance Co [1993] 1 SCR 252 at 262-264.
} 
(a) Occurrence liability policies are satisfactory in relation to automobile owners and drivers, where "the nature of the negligent act and the resultant damages are in almost all cases known upon the happening of the negligent act or shortly thereafter", but in the cases of professionals like doctors, lawyers and engineers, the fact of a liability may not be known for many years after the negligent act. "This is even more the case for manufacturers and other types of insureds who can cause damages by producing hazardous products or toxic waste."

(b) Successive occurrence liability policies arranged with different insurers over several years could lead to disputes between insurers about when the relevant occurrence happened, and accordingly which insurer had to bear the loss. "These kinds of disputes further added to the uncertainty in calculating insurers' actuarial risk, and also caused added expenses to the insurance industry in engaging in this type of litigation."

Insurers saw claims made policies as a way to provide cost-effective insurance coverage in relation to professional liability risks, by "avoiding the problems associated with the 'long-tail' nature of occurrence' policies. The date at which a claim was made would be easier to ascertain than the date at which an 'occurrence' happened, and more importantly, insurers would be better able to project the likely level of claims that would be payable under liability insurance policies."

Their Honours noted that: "Matters of this kind were not considered by the Australian Law Reform Commission in its 1982 report on Insurance Contracts which was the precursor to the Insurance Contracts Act."

Responding to that observation by his colleagues, Kirby $\mathrm{J}$ reviewed the background to the legislation and the section:

The history of s 54 of the Act reinforces the impression, given by the language of the section, that it is intended to have a broad remedial application. Before the Act, there existed in a number of Australian States legislative provisions that relieved insureds, in defined circumstances, from a failure to observe or perform a term or condition of a contract of insurance, or to give notice within the time required by a policy. Such provisions, according to their terms, exempted the insured from the harsh results that would otherwise have followed at common law: debarring the claim notwithstanding 
the fact that the insurer may have suffered little or no prejudice. The provisions of $\mathrm{s}$ 54 were obviously intended to build upon, and to extend, such relief and to make it available throughout Australia. ${ }^{123}$

It is true that the Australian Law Reform Commission's discussion of the clause of its draft Bill that became s 54 of the Act did not advert specifically to the operation of the section in the context of claims made type policies. However, the provision was deliberately cast in broad terms as was appropriate to a measure designed to extend and expand the pre-existing laws. Confirmation that this was the purpose of $\mathrm{s}$ 54(1) can be found in the fact that the sub-section is addressed to "the effect of a contract of insurance"; that it relates to a case where the insurer may refuse to pay a claim "either in whole or in part"; that it extends to a relevant "act" that by sub-s (6) includes an "omission"; that it relates not only to the acts and omissions of the insured but also to those "of some other person"; that it is addressed to the insurer's liability "in respect of the claim"; and that it permits a fair abatement of the insurer's liability by reference to any prejudice which the insurer has suffered "as a result of that act [or omission]". ${ }^{124}$

In the face of these many indications of the wide ambit of s 54, it is little wonder that this Court and other courts, have emphasised that the section must be given the broad application that its ample language and remedial purposes suggest. ${ }^{125}$

In view of earlier arguments that an omission under section 54 might not include an act which the policyholder was not obliged to do, McHugh, Gummow and Hayne JJ referred to Antico $v$ Heath Fielding Australia Pty Ltd: ${ }^{126}$

... it is important to recall that it was established in Antico that an omission for the purposes of s 54 may be a failure by the insured "to exercise a right, choice or liberty which the insured enjoys under the contract of insurance". It is not restricted to omissions to do something which an insured was obliged to do. Further, a relevant act or omission may be that of a person who is not a party to the contract of insurance. $^{127}$

Against this background, their Honours found that:

\footnotetext{
${ }^{123}$ [2001] HCA 38, above n120, at [74].

${ }^{124}$ [2001] HCA 38, above n120, at [75]

${ }^{125}$ [2001] HCA 38, above n120, at [76].

${ }^{126}$ Antico v Heath Fielding Australia Pty Ltd (1997) 9 ANZ Insurance Cases II61-371 at 77,081, (1997) 188 CLR 652 at 669 per Dawson, Toohey, Gaudron and Gummow JJ.

${ }^{127}$ [2001] HCA 38, above n120, at [22].
} 
Even if the fact that the third party made no demand on the insured within the period of cover were said to be an "omission" it is, nevertheless, of the first importance to recognise that the claim to which s 54 refers is the claim by the insured on the insurer that was actually made. It is not a claim for indemnity against some other demand (such, for example, as a demand assumed to have been made during the period of cover). Section 54 does not permit, let alone require, the reformulation of the claim which the insured has made. It operates to prevent an insurer relying on certain acts or omissions to refuse to pay that particular claim. In other words, the actual claim made by the insured is one of the premises from which consideration of the application of s 54 must proceed. The section does not operate to relieve the insured of restrictions or limitations that are inherent in that claim. ${ }^{128}$

\section{Moreover:}

... in the present case, the claim which the insured made on FAI was for indemnity against liability for an occurrence of which the insured first became aware during the period of cover. The effect of the contract of insurance is that FAI could refuse to pay that claim by reason only of the fact that the insured did not give notice of the occurrence to it. Section 54, therefore, requires the conclusion that FAI may not refuse to pay the insured's claim. The effect of the contract of insurance, but for s 54, would be that the insurer may refuse to pay the insured's claim by reason only of the omission of the insured to notify the occurrence which, at the time, was one which might subsequently give rise to a claim by the third party against it. That being so the section is engaged. No prejudice to the insurer's interests was suggested. ${ }^{129}$

Kirby $\mathrm{J}$ agreed that that policyholder was entitled to the benefit of section 54. After noting that claims made policies have been available "for decades in Canada, and as far back as the first half of [the twentieth] century in the United States" (quoted from Reid Crowther \& Partners Ltd $v$ Simcoe \& Erie General Insurance Co. ${ }^{130}$ ), Kirby J opined that "claims made type policies have become so common that it would be absurd to ignore the peculiarities of this form of insurance." ${ }^{131}$ Then, continuing later:

There is merit in the argument that, as far as its words permit, in the case of claims made type policies, s 54 of the Act should be construed to afford the relief contemplated in a way consistent with the maintenance of this type of insurance and not in a way that would be destructive of its availability. However, the duty of an

\footnotetext{
${ }^{128}$ [2001] HCA 38, above n120, at [41].

${ }^{129}$ [2001] HCA 38, above n120, at [46].

${ }^{130}$ [1993] 1 SCR 252, above n122, at 262.

${ }^{131}$ [2001] HCA 38, above n120, at [65].
} 
Australian court is, relevantly, to the law as expressed in the Act. The question is therefore how s 54 of the Act is to apply to "omissions" said to be applicable to a claims made type policy. Unless the meaning of the section, derived from its language, permits or requires a court to confine relief in such cases, any dissatisfaction with the operation of the section in respect of this class of insurance is a matter for legislative amendment. The judicial "struggle" with the requirements of the provision, as such requirements are found to be inherent in its language and apparent purpose, can only go so far. ${ }^{132}$

Therefore, despite many judicial attempts to constrain the operation of section 54 (catalogued by Kirby $\mathbf{J}$ at paragraphs [78] to [81] of his judgment), his Honour concluded:

The insured, otherwise entitled to indemnity, made a mistake. The mistake was an "omission". The insured omitted to follow its normal practice. It omitted to notify the insurer when it became aware of an occurrence which might subsequently give rise to a claim. Had it not made that "omission", but observed its ordinary practice, the insured would have been fully protected in the event of a "claim" made later. It would then have been deemed to have been made during the insurance period. No relevant prejudice was suffered, or asserted, by the insurer as a consequence of the insured's "omission". To refuse indemnity in such circumstances would be completely disproportionate to the "omission" on the part of the insured. It was thus the kind of "omission" that attracted a consideration of the provisions of s 54 of the Act. It follows that the majority of the Court of Appeal were correct to hold that s 54 of the Act applied to afford relief to the insured for its mistaken "omission". Once such relief was given, the insured was entitled to full indemnity. As Derrington $\mathbf{J}$ pointed out in the Court of Appeal, the result was not, as the insurer would have it, a serious departure from the "core", "essence" or "substance" of the insurance cover agreed between the parties. On the contrary, it was no more than the application to the policy provisions, for which the insured had paid its premium, of the relief from an immaterial "omission" provided by the remedial provisions of the Act. ${ }^{133}$

The insurer's appeal was dismissed.

\footnotetext{
${ }^{132}$ [2001] HCA 38, above n120, at [73].

${ }^{133}$ [2001] HCA 38, above n120, at [88].
} 


\section{George Tzaidas}

It might have been thought, given the comprehensive treatment of section 54 in Australian Hospital Care, that the application of that section was finally resolved. Muscillo (2001) certainly thought so: "The High Court's decision... appears to be the final word...". ${ }^{134}$ However, two years later the Supreme Court of New South Wales was faced with having to determine whether section 54 was relevant to the question of leave (to join an insurer to proceedings) under section 6(4) of the Law Reform (Miscellaneous Provisions) Act 1946, a question not considered in Australian Hospital Care.

The New South Wales case was George Tzaidas bht Vickie Tzaidas $v$ Child \& Ors. ${ }^{135}$ The background to the matter was that the mother of George Tzaidas, who was a carrier of Haemophilia B, gave birth to George on 16 November $1996 .{ }^{136}$ A few days later, George started having seizures. George's parents considered that the hospital was culpable.

Subsequently, "the weight of evidence" suggested that the hospital was "impecunious in the relevant sense", and would not be able to meet the claim brought by George's parents against the hospital and two of its medical staff. However, the Hospital was covered in respect of specified risks under a policy of insurance in force from 30 June 1999 to 30 June 2000 with Pacific Indemnity, a business name under which the insurer (CGU) traded. Grove J described the policy as:

... of a type sometimes described as a 'claims made and notified' or 'discovery' policy in the parlance of the insurance industry. The policy excluded acts, omissions etc prior to the 'specified retroactive date in the schedule' but the schedule in fact specified that 'the retroactive date is without limitation... ${ }^{137}$

Of particular note, was clause 4.1 of the policy, effectively a deeming provision:

If during the Period of Insurance, the Insured becomes aware of any fact, situation or circumstance, including any written or verbal notice of demand for compensation,

\footnotetext{
$\overline{{ }^{134} \text { Michele Muscillo "The Lessor of Two Evils: FAI General Insurance Co Ltd v Australian Hospital Care Pty Ltd" [2001] QUTLJJ }}$ at 20.

${ }^{135}$ George Tzaidas bht Vickie Tzaidas v Child \& Ors; Vickie Tzaidas v Child \& Ors; Con Tzaidas v Child \& Ors [2003] NSWSC 667, BC200304055.

${ }^{136}$ [2003] NSWSC 667 at [7] records that Haemophilia B is also known as Christmas Disease or Factor IX deficiency, and at [22] that the need for Factor IX may have been recognised by the hospital Registrar, but the hospital had none in stock.

${ }^{137}$ [2003] NSWSC 667, above n135, at [5].
} 
that may give rise to a Claims and elects during the Period of Insurance to give notice to Pacific Indemnity of such fact, situation or circumstance shall, for the purposes of this Policy, be deemed a Claims notified to Pacific Indemnity during the currency of this Policy. ${ }^{138}$

However, in order to join CGU to their claim against the hospital, Mr and Mrs Tzaidas needed to obtain leave in the Supreme Court, under section 6 of the Law Reform (Miscellaneous Provisions) Act. CGU's position was that "If the insurer is entitled to disclaim, leave must be refused: s6(4)."

Grove J noted that, as the insured (the hospital) had not given CGU notice of the potential claim during the relevant period, the terms of the policy allowed CGU to refuse the claim. However, that view did not take into account the statutory context, specifically section 54 of the Insurance Contracts Act 1984. Counsel in Tzaidas referred to an observation made by Powell JA in FAI General Insurance $v$ Jarvis, ${ }^{139}$ that the possibility of section 54 depriving section 6(4) of the Law Reform (Miscellaneous Provisions) Act of its effect was "a position for which no one seems yet to have argued." ${ }^{140}$ Unsurprisingly, CGU argued against it.

However, the Court in Jarvis had concluded that section 54 was not relevant to the leave question, because the answer to that question (it said) rested on whether the relevant contract of insurance permitted the insurer to disclaim liability, not on the factual questions (to be determined at trial) as to the extent of prejudice suffered by the insurer, and the nature of the policyholder's act or omission which allegedly gave the insurer a defence to the claim.

Nonetheless, Grove J articulated "an impression of some strength" that the engagement of section 54, and the lack of any demonstrable prejudice to the insurer's interests, would justify a different result to that indicated by Jarvis. However, while he was clearly sympathetic to the submission of counsel that Jarvis was impliedly overruled by Australian Hospital Care, his Honour, noting that Smart AJ in Hellier v AMP General Insurance $L t d^{141}$ had "expressed reservations about Jarvis but accepted that he was bound by it", concluded that Jarvis was also binding on him at first instance:

${ }^{138}$ [2003] NSWSC 667, above n135, at [6].

${ }^{139}$ FAI General Insurance v Jarvis [1999] NSWCA 23, (1999) 49 NSWLR 1.

${ }^{140}$ [1999] NSWCA 23, above n139, at [5].

${ }^{141}$ Hellier v AMP General Insurance Ltd [2002] NSWSC 866. 
As Lord Hailsham remarked in Cassell \& Co v Broome, ${ }^{142}$... 'in the hierarchical system of courts which exists in this country, it is necessary for each lower tier, including the Court of Appeal, to accept loyally the decisions of the higher tiers'. The comment is applicable to courts in the Australian federation.

The motions were dismissed, with costs to CGU.

In their application to the High Court for leave to appeal, ${ }^{143}$ the plaintiffs challenged the finding at first instance, mainly on the grounds that Jarvis was no longer good law in view of the later decision of the High Court in Australian Hospital Care. CGU opposed the grant of leave, arguing (inter alia) that the hospital was not aware during the period of insurance of the relevant circumstances that may give rise to a claim against it (so the hospital had no opportunity to deal with the matter in terms of clause 4.1), and that section 54 of the Insurance Contracts Act could not overcome the fact of the plaintiffs having failed to make a claim against the hospital during the period of insurance.

Santow JA in the High Court acknowledged that section 54 would, "prima facie," prevent CGU from declining the claim, if the conditions of section 54 were satisfied. His Honour, considering the decision in Jarvis, took the view that the "primary question" was whether in the event that section 54 would otherwise operate to allow the claim, the section 6(4) prohibition would be overcome by the application of section 54 .

His Honour noted that, in that event (section 54 overcoming the prohibition in section 6(4) of the Law Reform (Miscellaneous Provisions) Act), it would still be a discretionary matter for the Court as to whether leave under section 6(4) should be granted or withheld, which "fairly poses the question whether Jarvis can be distinguished, or should simply not be followed," in view of the decision in Australian Hospital Care.

Giles JA noted that although the matter before the Court of Appeal "was technically interlocutory", the decision was nonetheless of "critical importance for the plaintiffs and for CGU." Moreover, he noted, the standing of Jarvis was earlier queried, by Smart AJ in Hellier, and was now called into question by Grove $\mathrm{J}$ at first instance in this present matter, even though Smart AJ and Grove J both considered they were bound by the decision in Jarvis.

\footnotetext{
${ }_{142}$ Cassell \& Co v Broome [1972] 1 All ER 801at 809.

${ }^{143}$ Tzaidas v Child and Others [2004] NSWCA 252, (2004) 61 NSWLR 18, (2004) 208 ALR 651, (2004) 13 ANZ Ins Cas 61-617, BC200404824.
} 
Giles JA referred to Bailey $v$ New South Wales Medical Defence Union Ltd, ${ }^{144}$ in relation to the ancestry of section 6 of the Law Reform (Miscellaneous Provisions) Act. He noted that the leave requirement was first introduced in section 9 of the Law Reform Act 1936 (NZ), but without the words now found in s 6(4), "Leave shall not be granted in any case where the court is satisfied that the insurer is entitled under the terms of the contract of insurance to disclaim liability, and that any proceedings, including arbitration proceedings, necessary to establish that the insurer is so entitled to disclaim, have been taken". Giles JA referred to the stated intention of this "New South Wales addition":

... that the insurer should be able to raise equities as between himself and the insured [and]... that the liability of the insurer will be only the liability he has contracted to undertake under the terms of the policy. ${ }^{145}$

The purpose of the leave requirement, in relation to the current matter, was to protect insurers from claimants who sought to bypass the policyholder, and bring direct action against the insurer. Giles JA noted that the prohibition "is a gloss upon the leave requirement [such that]... leave must be refused if the prohibition is found to apply, although it may be refused in the exercise of the general discretion even if the prohibition is not found to apply." Per McHugh and Gummow JJ (approved by Brennan CJ and Deane and Dawson JJ) in Bailey:

This provision is not directing the court that leave be denied only in a case where it is satisfied both of entitlement to disclaim liability and that necessary steps have been taken to establish entitlement to do so. Leave may be refused in other cases but must be refused in these cases. ${ }^{146}$

In any event, on the matter of leave Giles JA concluded that the prohibition could not apply unless the insurer was entitled to refuse the claim, and, per the second limb of section 6(4), "that any proceedings, including arbitration proceedings, necessary to establish that the insurer is so entitled to disclaim, have been taken." The second limb could not be disregarded, and was not satisfied by the application for leave - the required proceedings had to be "something outside the application." CGU argued that such proceedings were not necessary if the insurer's right to disclaim was obvious, but Giles JA did not agree:

\footnotetext{
${ }^{144}$ Bailey v New South Wales Medical Defence Union Ltd (1995) 184 CLR 399 at 440-444.

${ }^{145}$ New South Wales Parliamentary Debates, 9 April 1946, 2nd series, Vol 180, at 3177.

${ }^{146}$ (1995) 184 CLR 399, above n144, at 448 and 415.
} 
I do not think that is right. The proceedings are those "necessary to establish" the insurer's entitlement to disclaim liability (emphasis added) ... So long as the insurer's entitlement to disclaim liability is in issue, other proceedings are necessary to establish it. ${ }^{147}$

On the matter of section 54 of the Insurance Contracts Act, Giles JA noted that in Australian Hospital Care the High Court had found that section 54 could apply to the act (omission) or failure to give "timely notice of an occurrence which might give rise to a claim against the insured, under a deeming clause broadly similar to condition 4.1 of the policy in the present case." However, the decision in Australian Hospital Care was concerned with when section 54 could apply, not with whether it was relevant to leave under s 6(4): "I do not think it negated the reasoning or result in FAI General Insurance Co Ltd v Jarvis." ${ }^{148}$

Noting that the joint judgment of McHugh, Gummow and Hayne JJ in Australian Hospital Care was clear that section 54 can apply in the event of a failure to disclose a relevant circumstance during the period of cover, Santow JA considered it would be "contradictory and illogical to conclude that a comparable failure to co-operate would fall outside the remedial amplitude of s 54. Such a divergent result could not be reconciled with Australian Hospital Care." ${ }^{149}$ Moreover, he took the view that section 6, as a remedial provision, should not be construed narrowly. ${ }^{150}$

In any event, leave to appeal was granted, on the basis that a substantive appeal was the proper forum to determine the matter.

${ }^{147}$ [2004] NSWCA 252, above n143, at [18].

${ }^{148}$ [2004] NSWCA 252, above n143, at [27].

${ }^{149}$ [2004] NSWCA 252, above n143, at [120].

${ }^{150}$ [2004] NSWCA 252, above n143, at [121]. 


\section{Gosford City Council}

Tzaidas was really about the interpretation of section 6 of the Law Reform (Miscellaneous Provisions) Act, in the context of section 54, rather than the interpretation of section 54 itself, but in Gosford City Council v GIO General Ltd, ${ }^{151}$ the Supreme Court of New South Wales faced yet another attempt by an insurer to restrict the application of section 54 .

After considering the difference between claims made and claims made and notified policies (see Chapter II of this dissertation), and the reasons identified by McLachlin J in Reid Crowther \& Partners $v$ Simcoe \& Erie General Insurance Co, ${ }^{152}$ for the issuing of such policies (a means of providing liability insurance at reasonable rates while avoiding the problems associated with the "long-tail" nature of "occurrence" policies), Sheller JA observed that McHugh, Gummow and Hayne JJ in Australian Hospital Care had said that "matters of this kind were not considered by the Australian Law Reform Commission in its 1982 report on insurance contracts which was the precursor of the [Insurance Contracts] Act."

The facts that gave rise to Gosford City Council can be stated simply. The council obtained liability insurance cover from GIO General Ltd, the insurer, for the period 30 June 1989 to 31 December 1991. The policy included the following provision:

GIO will pay to or on behalf of the insured all sums for which the insured shall become legally liable to pay by way of compensation (excluding punitive and exemplary damages) in respect of ... A claim or claims made against the insured during the Period of Insurance arising out of any negligent act, error or omission committed or alleged to have been committed, by the insured in the conduct of the insured's business as specified in the Schedule.

Condition 3 of the policy required the insured to give the insurer notice in writing, as soon as possible, of any "occurrence, claim, writ, summons or proceedings or of any impending prosecution or inquest."

On 30 May 1991, the council informed its insurance broker about a potential claim, but neither the council nor the broker notified the insurer. In fact, three years passed before

\footnotetext{
${ }^{151}$ Gosford City Council v GIO General Ltd [2003] NSWCA 34, (2003) 56 NSWLR 542, (2003) 12 ANZ Ins Cas 61-566, BC200300808.

${ }^{152}$ Reid Crowther \& Partners v Simcoe \& Erie General Insurance Co (1993) 1 SCR 252 at 262-264.
} 
the insurer was notified, that notice being prompted by the council having received (in July 1994) a statement of claim alleging that the council had breached its duty to the claimant in relation to the approval of building work. The insurer declined to indemnify the council.

Fortunately for the council, the claim against it was later dismissed by consent, so the only remaining issue was the significant amount of costs incurred by the council for defending the proceeding as far as it went. The council issued proceedings against GIO for that sum, but was unsuccessful at first instance.

Sheller JA then records that, in this appeal from the first instance decision, the council sought to rely on Newcastle City Council v GIO General Ltd, ${ }^{153}$ where Bergin J [referred to in Sheller JA's judgment as Brennan J] had identified that section 40(3) of the Insurance Contracts Act substituted a statutory notice condition for any contractual condition of the kind referred to in section 40(1):

The insured submitted that s40(3) transformed the policy here in question into a discovery policy. So transformed, the effect of the contract of insurance was that the insurer might refuse to pay the claim by reason of the act of the insured in failing to give the notice in writing to the insurer of facts which might give rise to a claim against the insured before the insurance cover expired. This was the particular circumstance whereby s40(3) became operative. The insured relied upon s54(1) to submit that the insurer in terms of a policy so transformed could not refuse to pay its claim by reason only of the act of its failing, within the times prescribed in s40(3), to give notice in writing to the insurer of the facts which might have given rise to a claim. $^{154}$

Recounting the relevant history of cases about section 54, Sheller JA identified the following matters:

- FAI General Insurance Co Ltd v Perry: The majority (Gleeson CJ and Clarke JA) found that the insured under a discovery policy (discovery condition in the same terms as the discovery condition in Australian Hospital Care), having failed to give notice of the relevant occurrence, was not entitled to the benefit of section 54. ${ }^{155}$

\footnotetext{
${ }^{153}$ Newcastle City Council v GIO General Ltd (1997) 191 CLR 85.

154 (1997) 191 CLR 85, above n153, at 93-94.

${ }^{155}$ FAI General Insurance Co Ltd v Perry (1993) 30 NSWLR 89.
} 
- Greentree v FAI General Insurance Co Ltd: The Court of Appeal was concerned with a "claims made and notified" policy. The issue was whether or not the failure by a third party to make a claim on the insured was an "omission ... of some other person", within the terms of s54(1) of the Act. ${ }^{156}$ The Court held that it was not. Spigelman CJ said: "The absence of a claim on the insured does not create any 'effect' that an 'insurer may refuse to pay a claim' by the insured. Until the first kind of claim is made, no issue of a claim of the second kind arises at all." 157

- Greentree: Mason P said it was plain to him that the High Court in Antico v Heath Fielding Australia Pty Ltd, ${ }^{158}$ "was rejecting portion [sic] of the reasoning in FAI General Insurance Co Ltd v Perry, but not questioning the result in that case."159 Moreover, section 54 "was not available to cure the omission in Perry, because the effect of doing so would have altered the scope of the contract of insurance in such a way that it would have been impossible for the Court to find a sufficient causal connection between the terms of the policy and the insurer's refusal to pay a particular claim." 160

- Antico: Section 54 "does not operate to alter the contractual promise of the insurer to pay a claim. It is engaged when the doing of an act or the making of an omission would excuse the insurer from an obligation to pay a claim for a loss actually suffered by the insured." 161

- Permanent Trustee v FAI: Court said that Perry was "not inconsistent" with Antico, and that section 54 of the Act is not engaged if no claim has been made on the insured within the period of the policy. ${ }^{162}$

- Australian Hospital Care: The High Court overruled the decision in Perry, and rejected the reasoning in Greentree and in Permanent Trustee, but said that nonetheless the actual decision in each case was right. However: "Under an 'occurrence' based contract, no claim can be made under the contract unless the event insured against takes place during the period of cover. Under a 'claims made and notified' policy, if no demand is made by a third party upon the insured during the period of insurance, any claim that may subsequently be made by the insured on the insurer (that is, the claim to which s54 refers) would necessarily acknowledge

\footnotetext{
${ }^{156}$ Greentree v FAI General Insurance Co Ltd (1998) 44 NSWLR 706.

157 (1998) 44 NSWLR 706, above n156, at 710.

${ }^{158}$ Antico v Heath Fielding Australia Pty Ltd [1997] HCA 35, (1997) 188 CLR 652, (1997) 146 ALR 385, (1997) 71 ALJR 1210.

159 (1998) 44 NSWLR 706, above n156, at 721 referring to [1997] HCA 35, above n158.

${ }^{160}$ (1998) 44 NSWLR 706, above n156, at 722 per Mason P.

${ }^{161}$ [1997] HCA 35, above n158.

${ }^{162}$ Permanent Trustee Australia v FAI General Insurance Co Ltd (1998) 44 NSWLR 186 at 228, per Hodgson CJ.
} 
that indemnity is sought in relation to a demand not of a type covered by the policy (because not within the temporal limits that identify those demands in relation to which indemnity must be given)." 163

Sheller JA said he had quoted at length from Australian Hospital Care:

... to emphasise the distinction between a claim against the insured which is not of a type covered by a claims made or claims made and notified policy, namely a claim made against an insured outside its temporal limits, and a claim made against the insured within those temporal limits, and therefore covered, but not notified to the insurer within the time allowed. ${ }^{164}$

Sheller JA identified that, in the second case, the insurer might wish to decline the claim due to the policyholder's failure to give the required notice within the required time, but section 54 "may operate to prevent the insurer refusing to pay the claim."

However, in the case of a discovery policy, the policyholder's knowledge of a potential claim during the period of the policy would satisfy the requirement for "an event of the type contemplated by the policy" - hence "the insured's argument [in Gosford City Council] that s40(3) converted the policy into a discovery policy".

Sheller JA, concluding:

To invoke s40(3) the insured must have given notice in writing to the insurer of facts that might give rise to a claim against the insured as soon as was reasonably practicable after the insured became aware of those facts but before the insurance cover provided by the contract expired. This was not done. In my opinion, that is the end of the matter. The occasion for s40(3) to operate did not happen. Accordingly, the subsection does not apply to prevent the insurer contending that the claim is not within the policy. ${ }^{165}$

\footnotetext{
163 (2003) NSWCA 34, above n151, at [34] referring to [2001] HCA 38, above n120.

164 (2003) NSWCA 34, above n151, at [35].

165 (2003) NSWCA 34, above n151, at [37].
} 


\section{A and D Douglas Pty Ltd}

Notwithstanding the ascendant star of Australian Hospital Care, there were still some situations where section 54 was not applicable, such as where the policyholder did not become aware of the relevant circumstances (the circumstances ultimately leading to a claim) during the period of cover... since that lack of knowledge meant that the failure to notify a claim was not an omission. This was a situation identified in $A$ and $D$ Douglas Pty Ltd ACN 008404180 v Lawyers Private Mortgages Pty Ltd ACN 010556 751, ${ }^{166}$ although ultimately the insurer was required to indemnify the policyholder on other grounds.

In Douglas, the Australian Securities and Investment Commission (ASIC) had investigated the private mortgage lending business conducted by a firm of solicitors (MDRN). Investors, typically clients of MDRN's legal practice, advanced money for specified projects. MDRN received and advanced the investors' funds, and took (and realised if necessary) security for repayment of those funds. The applicant company had deposited funds with MDRN for lending to Rivett Project Results Pty Ltd (elsewhere referred to as Project Results) for use in a development project at Yandina. A Mr Rivett was a director and in effective control of Project Results. The applicants' funds were advanced as contemplated, but the Yandina project failed. QBE, as MDRN's insurers for 1999 and 2000, and St Paul, as insurers for the period 1 July 2000 to 30 June 2001, were named as first and second cross-respondents respectively.

The claims for hearing were recorded by the Court as being: ${ }^{167}$

- against both respondents for damages for misleading or deceptive conduct contrary to s 995 of the Corporations Law as it stood at the relevant time;

- against the trustee company for damages for breach of duty; and

- against MDRN for damages for breach of duty as solicitors.

The Court noted that:

\footnotetext{
${ }_{166}$ A and D Douglas Pty Ltd ACN 008404180 v Lawyers Private Mortgages Pty Ltd ACN 010556751 [2006] FCA 520, (2006) 14 ANZ Ins Cas 61-709, BC200603233.

${ }^{167}$ [2006] FCA 520, above n166, at [4].
} 
Almost all claims arise out of statements in promotional material sent by MDRN and/or the trustee company to the various applicants, in particular a document describing the proposed investment in the Yandina project (the "investment summary"). Some applicants claim to have relied on other documents..., but such reliance is generally in support of claims which also depend on the investment summary. Some applicants rely on oral statements. ${ }^{168}$

In relation to the claim against the trustee company for breach of duty, the applicants alleged "a duty to take reasonable care not to recommend, nor to make, an imprudent investment and that it breached such duty."

The respondents admitted that duty, but not the breach. The respondents also admitted "that MDRN acted as solicitors for the applicants in the making and management of the loan to Project Results, and that they owed to each applicant a duty to exercise reasonable skill and care in so acting" and (significantly) admitted to "a contravention of section 995 in relation to the asset position and negligence in relation to the asset position and reliance in respect of those investors." ${ }^{169}$

However, despite the respondents' admissions, St Paul continued (as recorded in the judgment) to "claim the right to avoid liability under a policy of insurance on the basis of fraud or dishonesty by MDRN in connection with various other statements upon which the applicants previously relied ... Those matters are also relevant to the claim against QBE."

In relation to the 2000 policy:

MDRN has, itself, asserted that [the answers given in the proposal form] constituted notification of circumstances out of which the present claims arose ... [and so] the present claims are not covered by the 2000 policy ... MDRN does not assert that it gave notice of a claim [under the 1998 policy], or of circumstances which might give rise to a claim, during the period of cover or the following 28 days. Rather, it purports to do so by para 19 of its cross-claim, relying on s 54 of the Insurance Contracts Act 1984 (Cth). ${ }^{170}$

However, it was MDRN's primary position that it was entitled to indemnity pursuant to the 1999 policy, and to a lesser extent the 2000 policy.

\footnotetext{
${ }^{168}$ [2006] FCA 520, above n166, at [5].

${ }^{169}$ [2006] FCA 520, above n166, at [18].

${ }^{170}$ [2006] FCA 520, above n166, at [638]-[639].
} 
Referring to Australian Hospital Care, the Court considered that the High Court had established that an insurer in QBE's position could not avoid payment under a policy relying solely on the policyholder's failure to notify the insurer of the claim during the period of cover, except to the extent permitted by section 54. Although MDRN's pleading did not say so, the relevant "act" for the purposes of section 54 was that failure to notify.

On the matter of whether the decision in Australian Hospital Care might be distinguished for present purposes, the court noted that the policy that was at issue in Australian Hospital Care did not include the "language of 'election' contained in cl 5.2 of the present policy" - viz: "If during the Period of Cover the Insured becomes aware of any fact or circumstance that might give rise to a Claim under this Policy and elects to give notice in writing to QBE of such fact or circumstance, then any Claim which may subsequently arise out of such fact or circumstance shall be deemed to be a Claim made during the Period of Cover..." (my emphasis). However, despite acknowledging that it "may be arguable that the High Court was not addressing a situation in which the parties had stipulated for an election, and that an election may not accurately be described as an 'omission'," the court in Douglas considered the contrary was also arguable, and proceeded on the basis that Australian Hospital Care was relevant to MDRN's claim under the 1998 policy. ${ }^{171}$

The Court further concluded, in relation to the alternative claim under the 1998 policy, and relying on section 54 of the Insurance Contracts Act, that the 1998 policy could only cover claims in relation to which the policyholder became aware of the relevant circumstances during the period of cover, and in relation to which notice was given to QBE. Even if section 54 addressed the failure to notify QBE, the policyholder's lack of knowledge of the relevant circumstances during the policy period was fatal to its claim as "cl 5.2 of the policy was not engaged so as to extend cover under the 1998 policy to claims arising out of any such matter. Section 54 has no relevant operation."

The Court awarded damages to the applicants (other than two of them), both on the statutory cause of action and in relation to negligent misstatement, and also determined that MDRN should recover against St Paul in relation to one applicant's claim, and against QBE in respect of all the other amounts that the applicants were entitled to recover from MDRN.

${ }^{171}$ [2006] FCA 520, above n166, at [641]. 


\section{Nettle}

Nettle v Mathieson Group Pty Limited and Anor, ${ }^{172}$ was another case where the insurer considered it could disclaim liability, and resist being joined to the substantive proceeding, by relying on section 6(4) of the Law Reform (Miscellaneous Provisions) Act. However, despite getting a taste of success before a judicial registrar, the insurer was subsequently joined as a party to the proceeding.

The judgment records that during 2002, the parties reached an agreement whereby Mathieson would design and supervise construction of rooms for Mr Nettle's practice as a plastic surgeon. Defects in the design and work led to delay in Mr Nettle being able to occupy the rooms, while remedial work was carried out. Proceedings were commenced against Mathieson in October 2005, some time after the death of Mathieson's sole director and shareholder in a motor vehicle accident in 2003. On 20 July 2006, the plaintiff filed a notice of motion seeking to join Vero as an additional defendant in the proceeding, as Mathieson had a professional indemnity insurance policy with Vero or its predecessor from 1 March 2001 to 28 February 2003. The "insuring clause" of that policy provided indemnity against:

... liability at law for compensation and claimant's costs and expenses arising from any claim or claims first made against the Insured and notified to the Company during the Period of Insurance resulting from any Breach of Duty in connection with the Business or Practice but not in respect of any such claim or claims resulting from any act error or omission occurring or committed prior to the Retroactive Date.

A clause headed "run-off" extended the cover to include:

... any claim or claims first made against the Insured after the expiration of the Period of Insurance in respect of any civil liability in the conduct of the Business or Practice by the Insured. Provided always that, such indemnity will ... only apply when the Insured has ceased carrying on the Business or Practice ... [and] in accordance with the terms and conditions of the Policy ... in force at the time the claim is first made against the Insured ... [and] be provided for no additional premium ... [and] remain in force for such period as the Company continues to underwrite the engineers Facility; and ... [shall] only apply if the Insured is not entitled to indemnity in respect of such claim under any other professional indemnity insurance policy issued after the expiry of the Period of Insurance of this Policy.

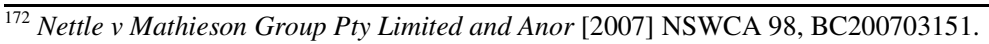


There was no evidence of Mathieson having effected insurance with another insurer after the expiry of Vero's policy (28 February 2003), and neither Vero nor Mathieson's accountants and insurance brokers were able to find a policy in force after that date.

However, the parties to the proceedings were agreed that Mathieson had made no claim on Vero during the period of Vero's policy.

Vero argued that it could disclaim liability, relying on section 6(4) of the Law Reform (Miscellaneous Provisions) Act and the appeal decision in Tzaidas $v$ Child ${ }^{173}$ Accordingly, the judicial registrar dismissed the plaintiff's motion, and Vero was not joined to the proceeding. This was despite the judicial registrar also finding that she was "not able to determine that prejudice suffered by Vero would result in its liability being reduced to nothing, in terms of s 54(1) of the Insurance Contracts Act ... [due to] a significant evidentiary gap, which I believe must dispose of the application in the exercise of the general discretion provided for in the section." The judicial registrar observed that, if the order was made:

Vero would be forced to defend proceedings and undertake further inquiries, which may result in another insurer being located ... [and] appropriate steps should [to prove the non-existence of a subsequent policy] be taken before consideration is given to joining an insurer who went off risk nearly six months before the principal of the defendant died. ${ }^{174}$

The plaintiff sought leave to appeal the judicial registrar's decision to the Court of Appeal. The Court of Appeal, referring to the "evidentiary gap" identified by the judicial registrar, found:

[there was] nothing in her reasons that discloses any relevance of that matter, and if attention was confined to matters disclosed in her reasons, it would follow that the discretion was exercised on the basis of an irrelevant consideration, and appellate intervention would be justified ... However, in this Court our attention was drawn to para (e) of the run-off clause, which could make the existence of another policy relevant, in that if there were another policy, that could preclude MG and thus the plaintiff having the benefit of the run-off clause. However, that in turn raises the

\footnotetext{
${ }^{173}$ [2004] NSWCA 252, above n143.

${ }^{174}$ From the judicial registrar's decision, as reported in [2007] NSWCA 98, above n172, at [13].
} 
difficulty that para (e) was never raised before the judicial registrar, giving substance to the plaintiff's submission that procedural fairness was denied. ${ }^{175}$

The Court of Appeal acknowledged that the onus of proof rests with the applicant for leave under section 6(4) of the Law Reform (Miscellaneous Provisions) Act, to demonstrate an arguable case that the insured (in this case Mathieson) had "entered into a contract of insurance by which the [insured] is indemnified against" the liability in question - referring, as the Court did, to the words used in section 6(1). However, in the absence of any evidence of another insurance policy, and in the circumstances here where Vero had not made its argument about paragraph (e) to the judicial registrar, there was no impediment to a finding under section 6(1), and the Court could not justify refusing leave under section 6(4). Moreover:

... while the question of whether there was a policy after 28 February 2003 could be relevant to Vero's liability under the run off clause, it has no relevance to the alternative ground of liability on which the plaintiff relied, namely liability under the insuring clause together with s 54 of the Insurance Contracts Act, as interpreted in FAI v Australian Hospital Care. ${ }^{176}$

Accordingly, the judicial registrar's decision was set aside, and Vero was joined as a party to the proceeding.

\section{Aussie Tax}

The Court in Aussie Tax Pty Ltd v Markel Capital Ltd, ${ }^{177}$ had to address what was effectively a contest between insurers as to which of them should pay the respondent's claim, although the other insurer was not a party to the proceeding. Markel Capital Ltd (Markel) represented an insurer.

Mr Asquith was, from 1999 or earlier, a certified practising accountant conducting at least part of his business through one or more companies "apparently under his control", including the company Aussie Tax Pty Ltd (Aussie Tax).

\footnotetext{
175 [2007] NSWCA 98, above n172, at [18]-[19].

${ }^{176}$ [2007] NSWCA 98, above n172, at [24].

${ }^{177}$ Aussie Tax Pty Ltd v Markel Capital Ltd [2008] VSC 592, BC200811380.
} 
The judgment records that from July 1999 to about October 2001 Mr Asquith and Aussie Tax (together referred to as the plaintiffs) gave professional advice to a group of clients, who later (in 2006) commenced a proceeding against the plaintiffs "alleging a breach of their professional duty of care with respect to that advice." In January 2007, that proceeding was settled by way of an agreement that Aussie Tax would pay $\$ 935,000$ to the clients.

In relation to professional indemnity insurance, the plaintiffs had joined a scheme operated by the Australian Society of Certified Practising Accountants, and subscribed to policies of insurance under that scheme for the period 30 September 1999 to 30 September 2000 with GIO General Ltd ("the 1999 policy"), for the period 30 September 2000 to 30 September 2001 with Lloyds ("the 2000 policy"), and for the period 30 September 2001 to 30 September 2002 also with Lloyds ("the 2001 policy"). In February 2002, the plaintiffs advised the underwriter of the 2001 policy regarding the anticipated claim, and in the same month submitted a claim form seeking indemnity in respect of that claim. This proceeding sought a declaration that the insurer represented by Markel was liable to indemnify the plaintiffs in relation to their civil liability to the clients.

The insuring clauses in the 2001 policy read:

The Insurers will indemnify the Insured in respect of any civil liability whatsoever and whensoever incurred in connection with the Practice in respect of which a claim is first made against the Practitioner, the Firm or the Company, as the case may be, during the Period of Insurance and which is reported to Insurers...

(a) during the Period of Insurance; or

(b) within 30 days after the Period of Insurance provided that a replacement policy commencing from the expiry of the Period of Insurance is effected with the Scheme", but the insurers were not required to indemnify the plaintiffs "in respect of any civil liability or loss arising from ... Any circumstances of which the Practitioner, the Firm or the Company, as the case may be, knew, or a reasonable person in the circumstances could be expected to know, prior to the Period of Insurance, to be circumstances likely to give rise to a claim against the Insured in respect of civil liability ...

It was agreed for the purposes of this preliminary trial that: 
... the plaintiffs knew prior to the period of insurance of the 2001 Policy, of circumstances which they knew to be circumstances likely to give rise to the clients' claim. Accordingly, exclusion clause 1(a) would have the effect of defeating their claims for indemnity under that policy. ${ }^{178}$

The plaintiffs therefore relied on a continuity extension provision (extension cl 4 to the 2001 policy), and the issue to be determined by the Court was whether this continuity extension was "engaged". The terms of the continuity extension included: ${ }^{179}$

If:

(a) during the Period of Insurance... a claim is first made against the Practitioner, the Firm or the Company, as the case may be, which arises from circumstances which occurred prior to the Period of Insurance; or... circumstances are first reported to the Insurers;

and

(b) the Practitioner, the Firm or the Company, as the case may be, knew, or a reasonable person in the circumstances could be expected to have known, at a point in time prior to the Period of Insurance, that the circumstances were likely to give rise to a claim against an Insured;

but

(c) the circumstances were not reported prior to the Period of Insurance and, as a result, the Insured is not entitled to indemnity under any preceding policy; and (d) the Practitioner, the Firm or the Company, as the case may be, has been insured under the Scheme continuously from the point referred to in paragraph (b) until commencement of the Policy...

\section{[THEN]}

exclusion 1(a) will not apply to the claim or to any claim arising from the circumstances; and ... the Insurers will not avoid this Policy or reduce their liability under this Policy by reason of the failure to disclose the circumstances prior to commencement of this Policy, unless the failure was fraudulent; but... the liability of the Insurers will be reduced by the amount that fairly represents the extent by which

\footnotetext{
${ }^{178}$ [2008] VSC 592, above n177, at [10].

${ }^{179}$ Laid out differently here, to facilitate reading.
} 
the insurers could have mitigated their liability under the policy which was current at the point in time referred to in paragraph (b), had the circumstances been duly reported under that policy; For the avoidance of doubt, this extension will not apply if any Insured is entitled to indemnity under any preceding policy in respect of a claim arising from the circumstances.

It was agreed that the requirement of paragraphs (a) and (b) were satisfied, and that in relation to paragraph (c) the circumstances were not reported prior to the period of insurance under the 2001 Policy (the period commencing 30 September 2001), so the issue was whether, as a result of this, the plaintiffs were not entitled to indemnity under any preceding policy:

The contention of Markel is that the plaintiffs were and are entitled to indemnity under the 1999 Policy or the 2000 Policy. This produces the curious result that the trial concerned the liability of an insurer which is not a party to the litigation and which is, therefore, not presenting argument against its liability and is not bound by a finding adverse to it. And the plaintiffs find themselves now in the position of presenting the absent insurer's case against a claim which they, the plaintiffs, may well have to pursue later if the contentions of Markel are made out. ${ }^{180}$

All three policies were claims made and notified policies, requiring any claim to be made on the insured and reported to the insurer within the period of insurance. All three policies were also subject to an identical discovery provision, granting indemnity where a claim on the insured was not made until after the expiry of the period of insurance so long as the insured had given notice of relevant circumstances to the insurer during the policy period. The discovery provision in each policy read:

If during the Period of Insurance the Practitioner, the Firm or the Company, as the case may be, becomes aware of any circumstances which may subsequently give rise to a claim against the Insured in respect of civil liability, and (a) during the Period of Insurance; or (b) within 30 days after the Period [of] Insurance provided that a replacement policy commencing from the expiry of the Period of Insurance is effected with the Scheme the Practitioner, the Firm or the Company, as the case may be, gives notice to the Insurers of those circumstances, then the Insurers are not relieved of liability under this Policy in respect of any such claim, when made, by reason only that it was made after the expiration of the Period of Insurance.

${ }^{180}$ [2008] VSC 592, above n177, at [12]. 
The parties agreed that the plaintiffs became aware of the relevant circumstances during the periods of the 1999 policy and the 2000 policy (some claims in one period, some in the other), although the plaintiffs failed to give notice to the relevant insurer in either case.

The plaintiffs argued that, as the earlier 1999 and 2000 insurers were not notified, they were not entitled to indemnity under those policies, and the continuity extension under the 2001 policy would therefore engage. However, Markel contended that section 54 of the Insurance Contracts Act 1984 operated to preserve the plaintiffs' rights under the 1999 and 2000 policies, thereby enabling Markel to avoid liability.

In view of these arguments, the Court considered that the "immediate questions" were whether, in relation to each of the 1999 and 2000 policies, the insured plaintiffs were "not entitled to indemnity under that policy" as a result of their failure to report the known circumstances to the relevant insurers for those years. ${ }^{181}$

On the basis of the decision in Australian Hospital Care, the Court concluded that the plaintiffs' failure to notify the 1999 insurer of the relevant circumstances was an act of the insured in terms of section 54(1) of the Insurance Contracts Act - which, having regard to section 54(6), includes omission. Although a further requirement for the operation of section 54(1) was whether the insurer may refuse to pay the claim as a consequence of the insured's omission, the effect of insuring clause 1 was that the 1999 and 2000 insurers (like the insurer in Australian Hospital Care) could disclaim if the relevant circumstances were not notified during the specified notice period. As there was no other basis for denying liability, section 54(1) prevented the insurers from disclaiming - "the liability of the 1999 insurer under insuring clause 1 was engaged", as was that of the 2000 insurer. ${ }^{182}$

Moreover, as "the insured is entitled to indemnity under the 1999 policy and under the 2000 policy, the continuity extension [in the 2001 policy] does not engage." ${ }^{183}$

\section{Triple C Furniture}

Just when we thought the earth had settled, along comes another case to challenge the boundaries of section 54. Johnson $v$ Triple C Furniture \& Electrical P/L involved the

${ }^{181}$ [2008] VSC 592, above n177, at [17].

${ }^{182}$ [2008] VSC 592, above n177, at [24] and [27].

${ }^{183}$ [2008] VSC 592, above n177, at [28]. 
death of a company director, while flying in his company-owned plane, due to his having been "grossly careless in his control of the aircraft." ${ }^{184}$ The director's wife, Mrs Johnson, brought proceedings against the company, alleging that it was vicariously liable for $\mathrm{Mr}$ Johnson's actions as an employee. The action against the company did not end until about ten years after the crash.

The company had a policy of aviation insurance, which included cover for claims arising from negligence. However, the insurer contended that section 54 did not allow the loss in this case to be brought out of time.

As Mr Johnson had been flying without having completed a required flight review within the two years immediately before the accident, the Court considered that the claim against the insurer would be dismissed unless section 54 of the Insurance Contracts Act was engaged to avoid that outcome.

The Court, comprising Holmes, Chesterman and White JJA, record:

The respondent submits that the appellant, as insurer, refused to pay a claim by reason of some omission of Mr Johnson ("some other person") which occurred after the policy was entered into so that s 54(1) applies to prevent the insurer refusing to pay the claim by reason of that omission. ${ }^{185}$

The Court concluded that section 54 did not make the insurer liable to pay the claim, as the pilot's failure to complete the flight review was not an omission as the word is ordinarily understood:

There is an immediate problem in characterising the prohibition on Mr Johnson's flying as an omission. The word carries with it an implication or connotation that the thing omitted, the thing not done, was something which was within the power of the omitter to have done. An omission may be deliberate or inadvertent, but whatever its cause one cannot, I think, be said to omit to do something which is beyond one's capacity to do. A candidate for an examination who fails is not ordinarily described as having omitted to pass. An athlete beaten in a contest does not omit to win. ${ }^{186}$

\footnotetext{
${ }^{184}$ Johnson v Triple C Furniture \& Electrical P/L [2010] QCA 282.

${ }^{185}$ [2010] QCA 282, above n184, at [66].

${ }^{186}$ [2010] QCA 282, above n184, at [70].
} 
Based on the earlier decisions in Antico and Australian Hospital Care, the Court in Triple $C$ Furniture identified that the "acts or omissions by reason of which the insurer may refuse to pay a claim are not acts or omissions which change the facts on which a claim is based." ${ }^{187}$

Putting it another way: "Because Mr Johnson had not satisfactorily completed the flight review, the respondent's claim for indemnity under the policy was excluded. The omission cannot change that, and is not of the kind with which s 54 is concerned." ${ }^{188}$

\section{Summary}

The change wrought by Australian Hospital Care was far-reaching, and effectively disposed of the myriad of constructions that had earlier been adopted to limit the application of section 54 of the Insurance Contracts Act. However, as mentioned above, the Australian insurers have almost universally removed contractual deeming provisions from their contracts of insurance. Clearly, section 54 cannot operate on something that is not present. However, the 'final' outcome also rests on the terms of section 40, which is a statutory deeming regime whereby notification of relevant circumstances during the policy term establishes a claim against that policy term. But for the existence of section 40 , it seems likely that insurers would have continued their earlier campaign to exclude claims made policies from the ambit of section 54 .

\footnotetext{
${ }^{187}$ [2010] QCA 282, above n184, at [80].

${ }^{188}$ [2010] QCA 282, above n184, at [83].
} 


\section{New Zealand After 1977}

From the discussion in Chapter III of this dissertation, it can be seen that in 1977 the concept of the 'intermediate' term was, at best, in a vestigial state. Hongkong Fir, which does not even use the word (although it is included in the catchwords in at least one report) had been decided about 15 years beforehand, but that case merely introduced the notion of a new application of equity, in the context of a case that was far removed from time limitations and contracts of insurance.

\section{A Insurers Could Decline Claims in Cases of Late Notification}

The future course of the debate about what came to be called intermediate clauses could not be known in 1977, but what was known was that insurers were, as the law stood then, able to decline claims in circumstances where time limits had been breached.

In New Zealand, the common law position was very clearly established as early as 1887 by the Supreme Court (as it was then) in Hollister v. Accident Association of New Zealand, ${ }^{189}$ where the terms of the relevant insurance policy required any claim to be notified to the insurer within seven days of the relevant accident. Accordingly, a claim lodged eight days after the accident was out of time, and, accordingly, the claim was declined on the basis that a condition precedent to the insurer's liability (the notice of claim provision) had not been complied with. Prendergast CJ was emphatic:

I do not think there can be any doubt that this [notice requirement] is a condition precedent-that this stipulation made is a requirement which is a condition precedent. It is not in the nature of a contract, the breach of which could be remedied by a cross action for damages, the intention of the parties being that it is a condition to be performed, otherwise there can be no claim. That is the clear meaning, and although, no doubt, as Mr Pitt has pointed out, in all the reported cases with regard to accident policies, there seems to be an express stipulation that the notices should be conditions precedent, yet, it would equally be so without this express stipulation. ${ }^{190}$

Although it took some 90 years for that situation to be addressed, in April 1975 the Contracts and Commercial Law Reform Committee (by way of its report Aspects of

\footnotetext{
${ }^{189}$ Hollister v. Accident Association of New Zealand (1887) 5 NZLR 49 (SC).

${ }^{190}$ (1887) 5 NZLR 49 (SC), above n189, at 49.
} 
Insurance Law) ${ }^{191}$ argued that insurers' entitlement to decline claims on the grounds of the policyholder's failure to comply with a time limit for notifying a claim, should be prescribed, unless the insurer was prejudiced by the delay.

\section{B Insurance Law Reform Act 1977, section 9}

In fact, the resulting New Zealand legislation to address this issue, section 9 of the Insurance Law Reform Act 1977, closely reflected the wording of the Instruments Act 1958 provision in Victoria, Australia, in relation to non-life claims. While the prejudice aspect of that provision applied to all insurance contracts in Victoria after 1958 - until the Instruments Act was overtaken by the Insurance Contracts Act 1984 (Cth) - the New Zealand section did not incorporate a prejudice provision in relation to life insurance claims arising from the death of the insured person. Commenting on this particular aspect, Tarr (1985) ${ }^{192}$ said:

Time limits for the notification of claims in the life insurance context could lead to monstrous results; for example, an insured could die and his representatives could fail to give the required notice in time through ignorance of his death or of the fact that he was insured. Moreover, the justifications for insurers imposing time limits for the notification of claims are much weaker in relation to life insurance. Subrogation rights arise only in respect of contracts of indemnity and have no operation in the life insurance arena with the consequence that an insurer cannot be prejudiced through a failure to proceed timeously against some third party to recoup payment made to the life insured's representative. In addition, adequate and prompt investigation of claims is of much more benefit to the insurer in the non-life area, especially in the insurer's endeavours to detect fraudulent claims arising out of property damage or loss. ${ }^{193}$

However, in relation to contracts of general insurance, and as per the Victorian legislation, a key feature of this new section 9 was the introduction of an equitable test, as per section 9(1)(b), such that a claim could only be refused if the policyholder's failure to comply with a notice provision had prejudiced the insurer to such an extent that "it would be inequitable if such provision were not to bind the insured."

\footnotetext{
${ }^{191}$ Contracts and Commercial Law Reform Committee Aspects of Insurance Law (Wellington, 1975) at [21].

${ }^{192}$ AA Tarr Insurance Law in New Zealand (The Law Book Co., NSW, Australia, 1985).

${ }^{193}$ Tarr, above n192, at 158 .
} 
While section 9(1)(b) refers specifically to prejudice, that term itself is subject to an equitable consideration, which is arguably a reference to equity itself - the same equity that is referred to in section 90 of the Judicature Act (see discussion in Chapter III of this dissertation).

Accordingly, in New Zealand the common law rules touching on compliance with time limits in contracts of insurance are modified by way of section 9 of the Insurance Law Reform Act 1977 (see Appendix 1 for full text), part of which says, in relation to non-life insurance policies:

A provision of a contract of insurance prescribing any manner in which or any limit of time within which notice of any claim by the insured under such contract must be given or prescribing any limit of time within which any suit or action by the insured must be brought shall... bind the insured only if in the opinion of the arbitrator or Court determining the claim the insurer has in the particular circumstances been so prejudiced by the failure of the insured to comply with such provision that it would be inequitable if such provision were not to bind the insured.

Consequently, if late claim notification (in relation to a non-life policy, where a time is specified for notification) results in the insurer being prejudiced to the point of inequity, the claim may be wholly denied. In contrast, the current Australian legislation, as per section 54 of the Insurance Contracts Act 1984 (Cth) (see Appendix 1, and Chapter V of this dissertation), provides that a claim may be "reduced" where the insurer's interests are prejudiced by the late notification or other relevant circumstances.

As noted earlier, it does not appear that claims made policies were given much thought when section 9 of the Insurance Law Reform Act was drafted, and it was probably thought that the section would principally affect occurrence policies.

Subsequently the New Zealand Law Commission has expressed the view that section 9 "changes the bargain in a way that is unfair to insurers", ${ }^{194}$ partly in response to the way section 9 has been found to affect deeming provisions in claims made policies. However, the section has largely stood the test of time, having now been operative for over 30 years. During that time, several significant court decisions have clarified the meaning of the section in relation to claims made insurance policies.

${ }^{194}$ New Zealand Law Commission Report 46: Some Insurance Law Problems (NZLC, E 32 AH, May 1998) at 23. 


\section{Sinclair Horder}

The first of these significant decisions was that of the New Zealand Court of Appeal in Sinclair Horder O'Malley \& Co v National Insurance Co of NZ Ltd. ${ }^{195}$

Sinclair Horder O'Malley \& Co (Sinclair Horder) were a firm of solicitors in Balclutha. It was not in dispute that the firm became aware in 1984 of circumstances likely to give rise to a claim against the partners of the firm. However, written notice of those circumstances was not given to the insurer until April 1986, shortly after the policy period ended. A condition of the relevant policy was that Sinclair Horder would give "immediate notice in writing" of any claim against them or of the receipt of notice from any person of an intention to make a claim against them.

The operative clause of the policy provided that National Insurance would indemnify Sinclair Horder "against any claim or claims which may be made against them or any of them during the period specified in the schedule."

Sinclair Horder were also required, under condition 3 of the policy, to:

... give to the Company immediate notice in writing of any circumstance, of which they shall become aware during the subsistence hereof, which is likely to give rise to a claim against them. Such notice having been given, any claim, to which that circumstance has given rise, which may be made after the expiration of the period specified in the Schedule shall be deemed for the purpose of this Policy to have been made during the subsistence hereof.

The Court of Appeal noted that the insurance cover at issue was a "claims made" policy, not a "claims made and notified" policy. However, quite apart from the obligation to give immediate notice of relevant circumstances, Sinclair Horder's policy, on the face of it, required such notice to be given during the subsistence of the policy if it was to trigger the contractual deeming provision in condition 3 .

Nonetheless, the Court found that section 9 of the Insurance Law Reform Act 1977 applied to such situations, in that condition 3 of the policy was a "provision of a contract of insurance prescribing ... [a] limit of time within which notice of any claim by the insured ... must be given", and, accordingly, condition 3 could only be binding as to time

${ }^{195}$ Sinclair Horder O'Malley \& Co v National Insurance Co of NZ Ltd [1995] 2 NZLR 257. 
if the insurer was prejudiced to the extent specified in section 9(1)(b) of the Act. Hardie Boys $\mathrm{J}$ in the Court of Appeal considered that: "The obvious intent of the section is to grant relief from time requirements on which the right to indemnity depends. The time requirement in condition 3 falls within that description."

Earlier in his judgment (in support of the majority decision), Hardie Boys J noted that the words "during the subsistence hereof" in the first sentence of condition 3 "plainly refer to the time the insured become aware of the circumstance, not to the giving of notice."

Moreover, he said:

... while s 9(1) prevents an insurer from invoking a time limit to avoid a liability which it would otherwise have, it does not create a liability where there would have been no liability even without the time limit. Thus a failure to give immediate notice of a claim made or of notice of intention to make a claim (condition 2) could not be redeemed under s 9(1) if the claim was made or the notice was given outside the policy period. But here it is condition 3 that is to be considered ... [In my opinion, the words] ... 'such notice having been given' [are] ... an extension of the cover ... that comes into existence only upon immediate notice to the insurer of a circumstance ... [but, by] reason of s $9(1)$, the insurer in the absence of prejudice cannot rely on the lack of immediacy. The notice is deemed to have been given timeously. It follows that 'such notice' in the second sentence is one that is deemed to have been given timeously. The insurer cannot be heard to say that it was not an immediate notice. ${ }^{196}$

The matter was therefore remitted back to the High Court for further hearing on the matter of prejudice.

This decision in Sinclair Horder was followed in Bradley West Clarke List v Keeman, ${ }^{197}$ to the extent that section 9 was found to be relevant to the effectiveness of time limitation in a claims made and notified policy, although, in terms of section 9(1)(b), the insurers of Bradley West were found to have been materially disadvantaged by Bradley West's delay of six years and ten months in relation to the giving of notice under the policy.

\footnotetext{
${ }^{196}$ [1995] 2 NZLR 257, above n195, at 265.

${ }^{197}$ Bradley West Clarke List v Keeman (1997) 9 ANZ Ins Cas 76,742.
} 


\section{QBE Insurance v Attorney General}

More recently, in 2005, the Court of Appeal handed down its decision in QBE Insurance Ltd $v$ Attorney-General. ${ }^{198}$ This case involved a claims made policy, where notice of relevant circumstances was given to the insurer during the policy term, but the thirdparty's claim was not lodged against the policyholder until about 3 years later. The Court found the circumstances at the time of notification did not trigger the insurer's liability to provide indemnity under the policy for that period - as there was no deeming provision in the policy for that period - and the Court declined to imply a policy term so as to treat circumstances notified as claims, "which the market of the day provided as a supplementary cover", in view of the recognised gap in coverage arising with a policy worded as this one was.

The $2005 Q B E$ decision is useful in confirming that an operative clause covering only claims made during the policy period is, notwithstanding the availability of section 9 , effective against a potential claim coming to light during the policy period but not being made until later, even in circumstances where the possibility of that claim has been advised to the insurer during the policy period. A "claim" which is not yet "made" cannot establish a right to indemnity under a claims made policy, in the absence of a deeming provision. Accordingly, as we see in the $Q B E$ case, an insured who cannot bring a claim in the period of a policy, but must disclose the possibility of that claim to its insurer for the ensuing period (with the likelihood of the identified circumstance then being excluded from cover for the ensuing period), is at some considerable disadvantage. The answer, as suggested in the Court of Appeal, is the purchase of supplementary (deeming) cover at the outset.

From a legislative perspective, justification for leaving section 9 more or less as it is and not trying to address the $Q B E$ outcome - is that the $Q B E$ case did not arise from "[late] notice of any claim by the insured" as such. It was simply a situation where the claim was not received by the insured in one policy period, and the availability of cover for the next period was affected by legitimate underwriting considerations. More concisely, MAF (the department represented by the Attorney-General) failed to obtain suitable cover in the first instance, and was denied indemnity for a claim falling outside the cover terms.

$\overline{{ }^{198} \text { QBE Insurance Ltd v Attorney General [2005] NZCA 193. Leave to further appeal to the Supreme Court was subsequently denied. }}$ 
As identified above, interpretation of section 9 of the Insurance Law Reform Act 1977 has been assisted by several notable court decisions. The position appears to be well established, now, in relation to late non-life claims.

\section{Claims made (not claims made and notified) insurance policies}

If the policy does not have a deeming provision (such that notice of relevant circumstances is deemed to be notification of a claim), and the third party's claim is not received by the insured during the policy period, then the claim is not payable against the policy for that period, although the claim may be covered by a later policy relating to the period during which the claim is received by the insured.

If the policy has a deeming provision, the deadline in that provision will make it subject to section 9, rendering that deadline non-binding unless the insurer is prejudiced to the point of inequity per section 9(1)(b).

\section{Claims made and notified insurance policies}

If the insured has not received the claim during the policy period, then the claim falls outside that period. Section 9 is not relevant because the trigger event for indemnity receipt of the claim by the insured - has not occurred, and so the issue of late notification to the insurer does not arise. However, an insured may still take advantage of a deeming provision in the policy (if it has one), which will operate in the same way as a deeming provision in a claims made policy.

If the third party's claim was received by the insured during the policy period, the insurer's liability in respect of a late claim - one notified after the deadline specified in the policy - will be determined by the extent to which the insurer has been prejudiced by that late notification to the insurer, based on the threshold test in section 9(1)(b). 


\section{Arguments For and Against Enacting a Statutory Deeming Provision in New Zealand}

\section{A Summary ... New Zealand and Australian Legislation Compared}

As noted earlier in this dissertation, New Zealand and Australia have each enacted legislation to alter the common law as it affects insurance contracts. In New Zealand, relevant provisions are found in the Insurance Law Reform Acts of 1977 and 1985. In Australia, the Insurance Contracts Act 1984 (Cth) includes a comprehensive regime for insurance contracts.

In relation to late claims, both regimes provide relief for situations involving late notification of a claim arising in the policy period, where the insurer is not prejudiced, or is only minimally prejudiced, by the delay.

However, it can be seen that the New Zealand legislation is less consumer-focused in two respects:

(a) Purchasers of professional liability insurance in New Zealand must pay an additional premium to obtain supplementary cover for possible claims (unconfirmed claims, not notified to the insured during the policy term) where relevant circumstances are advised to the insurer during the policy term - that is, to put in place the level of protection in that regard which is afforded by statute under section 40 of the Insurance Contracts Act in Australia. While it might be argued that Australian policyholders are already paying that additional premium (as part of the total premium they pay for claims made cover) to fund the statutory extension of cover arising from section 40, at least the overall cost is spread across all policyholders. On this basis, the Australian regime should be more costeffective overall, producing a net saving to consumers overall.

(b) Where, in New Zealand, an insurer is prejudiced by late notification, the availability of indemnity depends on whether (in terms of section 9, Insurance Law Reform Act 1977) the insurer has been "so prejudiced" by the failure of the insured to give timely notice, that it would be "inequitable" to require the insurer to honour the claim. In Australia, the issue (under section 54, Insurance Contracts 
Act) is the extent to which the insurer's liability should be reduced, rather than a threshold for liability.

The question arising from this situation, is whether the New Zealand legislation should incorporate a deeming provision like section 40 of the Australian Insurance Contracts Act (thereby avoiding the need for supplementary cover in that regard), and, separately, whether the threshold affecting liability under section 9(1)(b) of the New Zealand Act should be amended to instead reduce the insurer's liability by the amount that fairly represents the extent to which the insurer's interests were prejudiced as a result of the late notification - as per section 54 of Australia's Insurance Contracts Act.

A supplementary question here might arise from the terms of section 9(2) of the Insurance Law Reform Act 1977, which reduces liability rather than extinguishing it in the event of prejudice affecting certain property claims. A relevant background is that in 1977 New Zealand had very low interest rates, and the anticipated extra costs relevant to section 9(2) would undoubtedly have been the increased costs of materials and labour, rather than interest. Should section 9(2) be extended to affect claims under claims made policies? It is hard to see a reason why it shouldn't.

Australian insurers might say the regime in that country overly favours the insured person or business, particularly given the interpretation afforded section 54 in the context of a deeming provision. However, just as omitting the deeming provision in policies underwritten in Australia largely addresses that issue, by removing the notice provision that makes section 54 relevant, so the availability of supplementary cover may be perceived to address the absence of a statutory deeming provision in New Zealand. In the end it may come down, in the government's eyes, to consumer choice (the ability to buy an inferior insurance cover and save money) versus consumer protection (ensuring that all insurance policies of a particular type include the terms that a prudent consumer would prefer or regard as essential).

\section{B Attorney-General v $Q B E$}

Had a statutory deeming provision, similar to that in section 40 of the Insurance Contracts Act, been enacted in New Zealand at the same time as it was in Australia, the problem which arose in the MAF case would not have arisen. ${ }^{199}$

\footnotetext{
${ }^{199}$ [2005] NZCA 193, above n198.
} 
However, it is important not to forget that, in relation to claims where section 54 of the Insurance Contracts Act (which is broadly similar in objective to section 9 of the Insurance Law Reform Act 1977) applies, a specified time limitation in relation to notice may be ineffective where an insurer fails to prove prejudice arising from late notice by the insured. In New Zealand, section 9 has led to a number of cases where the insurer has had to pay a late-notified claim, simply because the terms of a deeming provision in the relevant policy brought section 9 into play. However, there have not been so many of these cases that insurers have sought to have Section 9 revoked in relation to claims made policies, also bearing in mind that the New Zealand provision allows an assessment of the extent of prejudice, rather than applying the more black and white approach adopted in the Australian provision.

Looking then at Section 54 of the Australian Act, it is clear that insurers quickly realized (albeit after it was enacted) the implications of that section in relation to claims made policies, but were very slow to implement the relatively easy solution now evident in the market place. It may be that the "easy" solution was simply not acceptable to the market initially - until a point was reached where enough insurers appreciated and were prepared to act on the problems presented by non-statutory deeming provisions - but, by removing such deeming provisions from policies, the insurance industry has now ameliorated the worst effects of section 54 (whether that has involved some kind of cartel behaviour is another question).

In any event, as it became clear, through a succession of cases (see Chapter $\mathrm{V}$ of this dissertation), that time limits in non-statutory deeming provisions were effectively torpedoed by section 54, insurers have moved to removing those deeming provisions. It is probably the case that very few, if any, claims made policies are now underwritten in Australia with a deeming provision. There was therefore the situation in Australia, that insurers were removing deeming provisions from their claims made policies, in view of the statutory deeming provision arising in Section 40 and their experiences in relation to section 54, but across the Tasman in New Zealand there was no equivalent to Section 40.

However it arose (perhaps, at least on the face of it, from AON's negligence), in 2002 MAF was issued with a claims made policy underwritten by QBE, which did not have a deeming provision. We then had the situation where MAF, during the period of that policy, had knowledge of circumstances which may give rise to a claim. MAF was obliged by the terms of the policy to report those circumstances to QBE, which it does. 
However, there is no deeming provision, and so that notification does not amount to notice of a claim. Accordingly, MAF must rely on being able to claim against the policy that is current when MAF itself receives the claim. The difficulty for MAF, is that not only was it required to notify QBE of the relevant circumstances as soon as MAF had notice of them, but MAF was also required to disclose the same information to its insurer for the subsequent years - which had the inevitable effect of leading that insurer to exclude the specific claim which might arise from those circumstances. In simple terms, MAF's inability to connect its knowledge of the relevant circumstances with the subsequent claim received, meant that MAF was unlikely in any circumstances to be covered by the policy against the type of situation which it encountered.

Subsequently, the Attorney-General (for MAF) litigated against QBE to recover the loss, relying largely on the expectation that the Court would take a purposive approach - that is, recognising that the purpose of MAF having the insurance was to cover situations such as that which arose, and therefore the finding that MAF's policy should be read as including such situations.

However, the High Court, and subsequently the Court of Appeal, took a different view, which was that a non-statutory deeming provision must have a cost associated with it (referring to some United States judgments), and was in any event a matter for negotiation between insurer and insured, and so it was not for the Court to write into the policy a provision that did not exist in the policy, given that it could have existed in the policy if the parties had chosen to extend their agreement in that way. In other words, the High Court and Court of Appeal adopted a conventional approach to contractual interpretation in the MAF case, which was effectively endorsed by the Supreme Court's refusal to grant leave for a further appeal. Although it is only speculation, it seems possible that the original policy wording, used for the 2002 year in MAF's case, was a policy intended for the Australian market, and that the broker or underwriter (or both of them) failed to consider the implications of New Zealand's statutory regime, which had no equivalent to section 40 of Australia's Insurance Contracts Act.

\section{Market Forces At Work}

The outcome of the MAF case underscores the significant distinction between the two insurance markets, in relation to deeming provisions. In Australia, consumers enjoy the benefit of a statutory deeming provision, which, as a way of mitigating the effect of 
section 54, has led to an industry practice of omitting deeming provisions from claims made policies. In New Zealand, in the absence of a statutory deeming provision, it is the industry practice to include a deeming provision, so as to ensure that relevant circumstances notified through an insurer are deemed to be notification of a claim, even if there is some delay in that claim being presented to the insured.

The problem, of course, is that those contractual deeming provisions in New Zealand are then subject to section 9 of the Insurance Law Reform Act 1977, and it is only the different effect arising from "prejudice" in relation to the New Zealand provision (in section 9) that makes the New Zealand regime palatable to insurers.

However, there may be other factors in play here too. For example, it may be much harder for an individual person to be a contractor in New Zealand than it is in Australia, since TNT Worldwide Express (NZ) Ltd v Cunningham, ${ }^{200}$ the subsequent Employment Relations Act 2000, ${ }^{201}$ and the Supreme Court's decision in Bryson v Three Foot Six Ltd. ${ }^{202}$ Therefore, although some New Zealand industries still prefer to engage workers as contractors rather than employees, that option is not as universally available as it is in Australia. Accordingly, the Australian work force has a much greater number of independent contractors, relative to employees, most being required (by their principals) to have comprehensive professional risks insurance. Consequently, on a per capita basis, there are far more professional risks insurance policies written in Australia than there are in New Zealand. There are, correspondingly, more complaints - that is, there are more claims, so there is more scope for argument. In these circumstances, it may be that the lesser number of claims made against policies issued in New Zealand, leading to fewer claims and fewer late claims, has simply kept the deeming provisions issue 'below the radar' more than has been the case in Australia.

At this point, it is useful to go back and review the situation as it was in Australia prior to the enactment of sections 40 and 54 of the Insurance Contracts Act 1984 (Cth). At that stage, most claims made policies had deeming provisions, but there was a huge amount of variation in the relevant terms. Insurers dictated those terms, and policyholders often did not know the extent of their cover and their obligations - except by obtaining professional advice as to the meaning of the relevant terms in the policy wording. The introduction of a statutory deeming provision in Australia, by way of Section 40, and the

\footnotetext{
${ }^{200}$ TNT Worldwide Express (NZ) Ltd v Cunningham [1993] 3 NZLR 681.

${ }^{201}$ Referring particularly to the meaning given to "employee" in section 6 of thatAct.

${ }^{202}$ Bryson v Three Foot Six Ltd [2005] NZSC 34.
} 
subsequent removal of deeming provisions from policies, has resulted in much greater consistency in the effective terms of these insurance policies across the marketplace. By contrast, New Zealand insurers are still offering a wide variety of policy wordings, at least in terms of deeming provisions. Some of these involve (largely ineffective) attempts to obviate the effect of section 9, but the real issue is that in New Zealand there is no universally held view amongst insurers as to how the law should be changed, despite the good example of developments in Australia.

It is relevant to note that the Australian legislation is federal (commonwealth) law, arising from the states and territories having ceded their authority in this area, although of course each state has input into the legislation that is developed and enacted by the Federal Parliament. There is a strong policy argument for keeping New Zealand legislation in this area of law closely aligned with the relevant federal legislation, as we have done (for example) in relation to trade practices law. This approach would at least be consistent with 'closer economic relations', ${ }^{203}$ although it would not prevent a divergence where there is some good justification for divergence. If it is true that the 1998-1999 policy wording that was at issue in the $2005 Q B E$ case was simply an Australian wording used in the wrong market, or was intended to be used in New Zealand with a supplementary deeming cover, that scenario would illustrate the dangers of New Zealand and Australia having widely divergent law in areas where major providers to the New Zealand market such as banks and insurance companies - are primarily headquartered in Australia, or rely on Australian branches for technical support and contract wordings.

\footnotetext{
$\overline{{ }^{203} \text { Loosely referring here to the Australia New Zealand Closer Economic Relations Trade Agreement (ANZCERTA or CERTA, or }}$ just CER), which came into force on 1 January 1983.
} 


\section{Conclusion}

It may be tempting to regard the lack of pressure for repeal of section 54 of the Insurance Contracts Act 1984 (Cth) (or for limiting its scope so as to make it not applicable to claims made policies) as evidence of a more stable market-place in that jurisdiction, operating within understood and agreed rules, in this area at least. However, that is probably a too-simplistic explanation for the insurers' change of stance. After all, section 54 removes some of their underwriting discretion, and restrains their ability to create new products within the claims made area - such as where marketing advantage might arise from the creative use of extensions to time limits.

Nonetheless, it is axiomatic that sections 54 and 40 operating together have indeed led to stability in the Australian claims made marketplace, and a further change might (as occurred following the introduction of section 54) lead to another round of uncertainty and expensive litigation.

Turning to the New Zealand situation, where there is no equivalent of section 40 , the repeal of Section 9 of the Insurance Law Reform Act 1977, or at least ceasing its application to claims made insurance, would arguably avoid the adverse outcomes insurers have seen (from the insurers' perspective) in relation to deeming provisions insurers would again be able to rely upon the time limits in deeming provisions in their policies. However, that would be a retrograde step from a consumer perspective. Firstly, policyholders would be returned to the pre-1977 situation, where delayed notification might cause a claim to be declined even if the insurer is not prejudiced. The small 'benefit' of greater certainty in the area of claims made insurance would undoubtedly (if section 9 was repealed) be outweighed by the certain detriment to holders of occurrence type policies and other insurance covers where deeming provisions are not used.

Amending section 9 to exempt claims made policies from its scope would introduce problems of definition - what is a claims made policy? what types of claims made policies are to be exempted or not exempted? how do we deal with hybrid policies? - and perhaps no greater certainty in the end than we presently have.

The Australian experience, of a statutory deeming provision coupled with a prejudice rule in relation to late notification/late claims, has produced a more consistent and consumerfriendly outcome than that which presently prevails in New Zealand. While New Zealand would want to avoid repeating the Australian experience in relation to how the statutory 
provisions are interpreted, perhaps by expressly adopting the significant Australian judgments (findings) into the terms of relevant legislation, convergence in this area of law would also recognise the fact that most of the claims made policies issued in New Zealand are underwritten by Australian insurers, and that many New Zealand businesses also operate in Australia (and vice versa).

\section{Stephen Bourne}

20 September 2011 


\section{Appendix 1}

A Insurance Contracts Act 1984 (Cth), section 40

\section{Certain contracts of liability insurance}

(1) This section applies in relation to a contract of liability insurance the effect of which is that the insurer's liability is excluded or limited by reason that notice of a claim against the insured in respect of a loss suffered by some other person is not given to the insurer before the expiration of the period of the insurance cover provided by the contract.

(2) The insurer shall, before the contract is entered into:

(a) clearly inform the insured in writing of the effect of subsection (3); and

(b) if the contract does not provide insurance cover in relation to events that occurred before the contract was entered into, clearly inform the insured in writing that the contract does not provide such cover.

Penalty: 300 penalty units.

(3) Where the insured gave notice in writing to the insurer of facts that might give rise to a claim against the insured as soon as was reasonably practicable after the insured became aware of those facts but before the insurance cover provided by the contract expired, the insurer is not relieved of liability under the contract in respect of the claim, when made, by reason only that it was made after the expiration of the period of the insurance cover provided by the contract.

\section{B Insurance Contracts Act 1984 (Cth), section 54}

\section{Insurer may not refuse to pay claims in certain circumstances}

(1) Subject to this section, where the effect of a contract of insurance would, but for this section, be that the insurer may refuse to pay a claim, either in whole or in part, by reason of some act of the insured or of some other person, being an act that occurred after the contract was entered into but not being an act in respect of which subsection (2) applies, the insurer may not refuse to pay the claim by reason only of 
that act but the insurer's liability in respect of the claim is reduced by the amount that fairly represents the extent to which the insurer's interests were prejudiced as a result of that act.

(2) Subject to the succeeding provisions of this section, where the act could reasonably be regarded as being capable of causing or contributing to a loss in respect of which insurance cover is provided by the contract, the insurer may refuse to pay the claim.

(3) Where the insured proves that no part of the loss that gave rise to the claim was caused by the act, the insurer may not refuse to pay the claim by reason only of the act.

(4) Where the insured proves that some part of the loss that gave rise to the claim was not caused by the act, the insurer may not refuse to pay the claim, so far as it concerns that part of the loss, by reason only of the act.

(5) Where:

(a) the act was necessary to protect the safety of a person or to preserve property; or

(b) it was not reasonably possible for the insured or other person not to do the act; the insurer may not refuse to pay the claim by reason only of the act.

(6) A reference in this section to an act includes a reference to:

(a) an omission; and

(b) an act or omission that has the effect of altering the state or condition of the subject-matter of the contract or of allowing the state or condition of that subject-matter to alter.

\section{Insurance Law Reform Act 1977, section 9}

\section{Time limits on claims under contracts of insurance}

(1) A provision of a contract of insurance prescribing any manner in which or any limit of time within which notice of any claim by the insured under such contract must be given or prescribing any limit of time within which any suit or action by the insured must be brought shall- 
(a) if that contract of insurance is embodied in a life policy and the claim, suit, or action relates to the death of the insured, not bind the insured; and

(b) in any other case, bind the insured only if in the opinion of the arbitrator or Court determining the claim the insurer has in the particular circumstances been so prejudiced by the failure of the insured to comply with such provision that it would be inequitable if such provision were not to bind the insured.

(2) Where-

(a) the insured under any contract of insurance to which subsection (1)(b) of this section applies fails to give notice of any claim in any manner or within any limit of time prescribed by the contract; and

(b) the cost of repairing, replacing, or reinstating any property when it falls to be met is greater than that which would have applied if the notice had been given in the manner or within the time so prescribed,-

that greater cost shall not constitute prejudice to the insurer for the purposes of subsection (1)(b) of this section, but the insurer shall not be obliged to apply or pay in repairing, replacing, or reinstating the property a greater sum than that for which he would have been liable if the notice of claim had been given in the manner or within the time so prescribed.

Compare: Instruments Act 1958, s 27 (Victoria) 


\section{Bibliography}

\section{A Bulletin Articles}

Clark, Kate and Landvogt, Michael "Insurance Contracts Act Reform" (Lander \& Rogers Insurance eBulletin, Lander \& Rogers, Australia, March 2010) <www.landers.com.au>.

Fetcho, John "Buyer Beware: What You Don't Know About Your Professional Liability Insurance Can Hurt You" (AANA NewsBulletin, American Association of Nurse Anesthetists, United States, March 2007) <www.aana.com>.

Newbrun, Ann and Tsang, Mandy "Insurance Contracts Amendment Bill 2010" (Mallesons Client Alert, Mallesons Stephen Jaques, Australia, 18 March 2010) $<$ www.mallesons.com>.

\section{B Conference Papers}

Kirby, Michael "Australian Insurance Contract Law: Out of the Chaos - A Modern, Just and Proportionate Reforming Statute" (Australian Insurance Law Association National Conference, Australia, 28 October 2010).

Michalik, Paul and McIntosh, Hamish "Insurance Law Update" (NZ Insurance Law Association Conference, New Zealand, 2005).

\section{Internet Articles}

Barry Nilsson Lawyers "It's Time - Insurance Contracts Amendment Bill 2010" (, Barry Nilsson Lawyers, Australia, 2010) <www.bnlaw.com.au>.

Bartlett, Kevin "Section 54 encounters more turbulence - Does section 54 of the Insurance Contracts Act apply to an exclusion relating to a breach of a Civil Aviation Regulation?" (Mondaq.com, Australia, 30 March 2011) <www.mondaq.com>. 
Dinkha, Olivia "Professional Indemnity Insurers Beware - Court of Appeal finds Managing Agent was occupier of Common Property" (Mondaq.com, Australia, 12 August 2010) <www.mondaq.com>.

Dorroh, Paul and Whisenand, Mary E "Understanding Your Claims-Made Professional Liability Insurance Policy" (, Marsh Affinity Group Services, US, 2000) <www.soa.org> Leonie Blazey "Rent Review and Delay - Part 2" (Property and Finance, Australia, 13 September 2011) <www.champion.com.au>.

Gold, Joshua "Understanding Time Sensitive Provisions" (Mondaq.com, United States, 14 August 2011) <www.mondaq.com>.

Lefton, Hartley "In A Pickle: The Limitation Of Relying On Insurance Contract Exclusions" (Mondaq.com, Canada, 11 August 2011) <www.mondaq.com>.

Leman, Peter "High Court Determines When An Occurrence Based Liability Policy Responds To A Leaky Building Claim" (Mondaq.com, New Zealand, 5 October 2009) $<$ www.mondaq.com>.

Mead, Patrick "Professional Indemnity Insurance - Claims Made and Notified Policies Sections 54 and 40(3) of the Insurance Contracts Act 1984 (Cth)" (Constructive Notes, Carter Newell Lawyers, Australia, February 2010) <www.carternewell.com>.

Morrow, Brooke "Common Meaning Of Term Of Exclusion Clause Prevented Indemnity Being Available" (Mondaq.com, Australia, 12 August 2010) <www.mondaq.com>.

Richardson, Barry "Claiming Against the Insurer of a Deregistered Company" (Mondaq.com, Australia, 12 August 2010) <www.mondaq.com>.

Sage, William $M$ "The Forgotten Third: Liability Insurance And The Medical Malpractice Crisis" (ProQuest, United States, 1 July 2004) <www.proquest.com>.

Schiffer, Larry P "The Index Clause: One Way To Stem The Effect Of Inflation On Long-Tail Claims Under Excess-Of-Loss Reinsurance Contracts" (Mondaq.com, United States, 17 February 2011) <www.mondaq.com>. 


\section{Issues Papers}

Australian Law Reform Commission "Australian Law Reform Commission submission to Review of the Insurance Contracts Act 1984 (Cth): Issues Paper on Section 54" (Australian Law Reform Commission, Australia, Undated)

Law Council of Australia "Exposure Draft - Insurance Contracts Amendment Bill 2009" (Law Council of Australia, Australia, 6 November 2009)

\section{E Journal Articles}

Anderson, Dan R "Developing Liability Risks and Insurance: Regulatory Impacts and Responses Over the 20th Century" [Winter 2000] 19 JInsReg 2 at 323.

Balco, John $\mathbf{J}$ "Managing risk in an engineering and environmental company" (June 1993) 40 RiskMan 6 at 53.

Born, Patricia and Boyer, M Martin "Claims-made and reported policies and insurer profitability in medical malpractice" (March 2011) 78 JRiskIns 1 at 139.

Carter, JW, Tolhurst, GJ and Peden, Elisabeth "Developing the Intermediate Term Concept" (Journal of Contract Law, 2006) at 268.

Dearden, DR and Burke, MR "Read all the Words in Your Malpractice Insurance Policy" (Quality Review in Anesthesia, US, March-April 2006).

Ferrara, Donna "Mergers and the claims-made policy: are you covered for claims that surface after the merger?" (September 2002) 49 RiskMan 9 at 32.

Griffin, Jeffrey P "Inapplicability of the Notice-Prejudice Rule to Pure Claims-Made Insurance Policies" [2009-2010] 42 ConnLRev 1 at 235.

Griffiths, Tim "Time limits in claims-made insurance in Australia and New Zealand" (1997) 5 IntILR 3 at 85. 
Kirby, Michael "Equity's Australian Isolationism" (2008) 8 QUTLJJ 2 at 444.

Kroll, Sol "The case for claims made" (August 2005) 52 RiskMan 8 at 49.

Lewins, Kate and Lo, Simon "Striving for Equilibrium: A Critical Analysis of Section 54" (June 2003) 10 MurUEJL 2 at $20<$ www.murdoch.edu.au>.

Malone, Cort T and Horne, Jane A "Should I Change D\&O Carriers?" (April 2009) 56 RiskMan 3 at 22.

Martin, John "A timing issue" (Property Law Journal, United Kingdom, 21 March 2005).

Muscillo, Michele "The Lessor of Two Evils: FAI General Insurance Co Ltd v Australian Hospital Care Pty Ltd" [2001] QUTLJJ at $20<w w w . q u t . e d u . a u>$.

Oettle, Kenneth F and Howard, Davis J "Zuckerman and Sparks: The Validity of 'Claims Made' Insurance Policies as a Function of Retroactive Coverage" [1985-1986] 21 Tort\&InsLJ at 659 .

Parker, John K "The Untimely Demise of the 'Claims Made' Insurance Form? A Critique of Stine v Continental Casualty Company" (1983) DetCLRev at 25.

Reidy, Andrew M "Subprime Insurance Coverage Battles Fallout: Part One" (June 2008) 55 RiskMan 6 at 24.

Sarnacki, David C "Getting What You Need For Your Office" (December 1995) 74 MIBarJ at 1301.

Schoenfeld, Anita and Parry, Arthur E "Claims-made vs occurrence coverage" (November 1992) 39 RiskMan 11 at 54.

Smith, Sean A "Too much risk: the impact of class action lawsuits on claims made insurance policies: H \& R Block, Inc v American International Specialty Lines Insurance Co" (Fall 2009) 74 MissLR 4 at 1171.

Shapiro, Leon E "Professional Liability Insurance" (October 2004) 46 ASHRAEJ 10 at 59. 
Tarr, AA "Insurance Law and The Consumer" (1989) 1 BondLR 1 at 79 $<$ epublications.bond.edu.au>.

Zimmerman, Philip "Directors and officers insurance update" (July 2002) 72 CPAJ 7 at 16.

\section{F Magazine Article}

Goodall, Jason "Upholding the exclusions" (NZ Lawyer, New Zealand, 1 April 2010) $<w w w . n z l a w y e r m a g a z i n e . c o . n z>$

\section{G Research Papers and Submissions}

Callinan, Rachel "Medical Negligence and Professional Indemnity Insurance Background Paper No 2/01" (NSW Parliamentary Library Research Service, Australia, May 2001).

Cameron, Alan and Milne, Nancy "Review of the Insurance Contracts Act 1984 (Cth): Report Into The Operation Of Section 54" (Commonwealth of Australia, Australia, 31 October 2003).

IBA Insurance Committee "The impact of local law on claims made policies, and the issues of late notification of claims and circumstances and time bars" (International Bar Association, 2008) <www.int-bar.org $>$.

Manning, Brent A "Issues Relating To Claims Made Insurance Policies" (Victoria University of Wellington, New Zealand, 1995).

New Zealand Law Commission "Section 9 of the Insurance Law Reform Act 1977 and claims made policies" (New Zealand Law Commission, New Zealand, 1998).

Merkin, Robert "Reforming Insurance Law: Is There a Case for Reverse Transportation?" (English and Scottish Law Commissions, United Kingdom, Undated). 
Royal \& Sun Alliance "Insurance Contracts Act 1984 (ICA) - Royal and Sun Alliance Response to Issues Paper on s54" (Royal \& Sun Alliance Insurance Australia Limited, Australia, 16 October 2003).

Traves, Samantha "Important Aspects Of The Proposed Reforms To The Insurance Contracts Act 1984 (Cth)" (Unpublished Research Paper, Australia, 15 May 2007).

\section{H Seminar Paper}

Merkin, Robert "Directors' and Officers' Insurance and the Global Financial Crisis" (Geoff Masel Memorial Lectures, Australia, October-November 2009).

\section{Books}

Burrows JF, Finn, Jeremy and Todd, Stephen MD Law of Contract in New Zealand (Butterworths, Wellington, New Zealand, 1977).

Dickens, Charles Bleak House (Chapman \& Hall Ltd, London, England, circa 1853).

Joske, PE and Brooking, Robert Insurance Law in Australia and New Zealand (Butterworths, Sydney, Australia, 1975).

Meagher, RP, Heydon, JD and Leeming, MJ Meagher, Gummow and Lehane's equity, doctrines and remedies (4th ed, Butterworths LexisNexis, Australia, December 2002).

Sutton, Kenneth Insurance Law in Australia (3rd ed, LBC Information Services, Sydney, Australia, 1999).

Tarr, AA Insurance Law in New Zealand (The Law Book Co., NSW, Australia, 1985). 